\title{
Use of SWAT to Model Impact of Climate Change on Sediment Yield and Agricultural Productivity in Western Oregon, USA
}

\author{
G. W. Mueller-Warrant, C. L. Phillips, K. M. Trippe \\ USDA-Agricultural Research Service, Forage Seed and Cereals Research Unit, Corvallis, OR, USA \\ Email: George.Mueller-Warrant@ars.usda.gov, Claire.Phillips@ars.usda.gov, Kristin.Trippe@ars.usda.gov
}

How to cite this paper: Mueller-Warrant, G.W., Phillips, C.L. and Trippe, K.M. (2019) Use of SWAT to Model Impact of Climate Change on Sediment Yield and Agricultural Productivity in Western Oregon, USA. Open Journal of Modern $\mathrm{Hy}$ drology, 9, 54-88.

https://doi.org/10.4236/ojmh.2019.92004

Received: March 26, 2019

Accepted: April 25, 2019

Published: April 28, 2019

Copyright $\odot 2019$ by author(s) and Scientific Research Publishing Inc. This work is licensed under the Creative Commons Attribution International License (CC BY 4.0).

http://creativecommons.org/licenses/by/4.0/

\begin{abstract}
Climate change predictions for the Pacific Northwest region of the United States of America include increasing temperatures, intensification of winter precipitation, and a shift from mixed snow/rain to rain-dominant events, all of which may increase the risk of soil erosion and threaten agricultural and ecological productivity. Here we used the agricultural/environmental model SWAT with climate predictions from the Coupled Model Intercomparison Project 5 (CMIP5) "high $\mathrm{CO}_{2}$ emissions" scenario (RCP8.5) to study the impact of altered temperature and precipitation patterns on soil erosion and crop productivity in the Willamette River Basin of western Oregon. An ensemble of 10 climate models representing the full range in temperature and precipitation predictions of CIMP5 produced substantial increases in sediment yield, with differences between yearly averages for the final (2090-2099) and first (2010-2019) decades ranging from 3.9 to $15.2 \mathrm{MT} \cdot \mathrm{ha}^{-1}$ among models. Sediment yield in the worst case model (CanESM2) corresponded to loss of $1.5-2.7 \mathrm{~mm} \cdot$ soil $^{-} \mathrm{y}^{-1}$, equivalent to potentially stripping productive topsoil from the landscape in under two centuries. Most climate models predicted only small increases in precipitation (an average of $5.8 \%$ by the end of the 21 st century) combined with large increases in temperature (an average of $\left.0.05^{\circ} \mathrm{C} \cdot \mathrm{y}^{-1}\right)$. We found a strong correlation between predicted temperature increases and sediment yield, with a regression model combining both temperature and precipitation effects describing $79 \%$ of the total variation in annual sediment yield. A critical component of response to increased temperature was reduced snowfall during high precipitation events in the wintertime. SWAT characterized years with less than basin-wide averages of $20 \mathrm{~mm}$ of precipitation falling as snow as likely to experience severe sediment loss for multiple crops/land uses. Mid-elevation sub-basins that are projected to shift from rain-snow transition to rain-dominant appear particularly vulnerable to sediment loss. Analyses of predicted crop yields indicated declining produc-
\end{abstract}


tivity for many commonly grown grass seed and cereal crops, along with increasing productivity for certain other crops. Adaptation by agriculture and forestry to warmer, more erosive conditions may include changes in selection of crop kinds and in production management practices.

\section{Keywords}

Climate Change, Sediment Yield, Soil Water Assessment Tool, SWAT, Coupled Model Intercomparison Project 5, CIMP5, Nash-Sutcliffe Efficiency, NSE

\section{Introduction}

Because civilization's survival is by definition dependent on reliable production of human food and animal feed, potential negative impacts of climate change on agricultural productivity in particular, and on the sustainability of numerous ecosystem services in general, are viewed with great alarm by the vast majority of scientists. Increases in temperature, loss of snow pack, and declining stream flow associated with climate change have already impacted the Pacific Northwest (PNW) of the United States, and are projected to continue doing so in coming decades [1]. Traditionally considered "water rich", the Willamette Valley in western Oregon is a large river basin with extensive agricultural, ranching, and forestry land uses that are potentially vulnerable to changing climate and water supply. While climate change impacts on water availability in this region have received considerable attention [2] [3] [4] [5] [6], an important related issue, largely overlooked, is the risk of soil erosion and subsequent impacts on agricultural and ecological productivity. With climate change predictions including increased winter precipitation [7], higher storm intensity [8], and a larger proportion of precipitation falling as rain rather than snow [9], there is potential for climate-related increases in sediment loading. The Soil Water Assessment Tool (SWAT) has been widely used to simulate water quality, sediment loading, and crop productivity responses to changing temperature, precipitation, crop management, and land use patterns across large scales [10] [11] [12].

In 2015, the PNW experienced a "snow drought" that had severe impacts on agricultural productivity and the environment. Despite normal precipitation levels, winter temperatures were $2.7^{\circ} \mathrm{C}-3.3^{\circ} \mathrm{C}$ above average, causing much of the precipitation to occur as rain rather than as snow [13]. Reduced discharge and high temperatures the following spring and summer limited water supplies and increased plant stress, resulting in estimated crop losses of 633 - 733 million USD in Washington State alone [14]. This combination of higher temperatures and reduced snowpack is illustrative of conditions that climate models project for the PNW by mid-century [13]. Although many climate models project normal or increasing levels of precipitation over coming decades [1], warming winter temperatures are expected to reduce snowfall, with almost all parts of western Oregon projected to shift out of rain-snow transition zones and become 
rain-dominant by the 2080s [4].

A warmer, and possibly wetter, climate is projected to shift streamflow timing toward the winter months, and increase runoff intensity [3]. While it can be expected that increased winter flows would increase winter sediment loadings, there has been little analysis of the implications of climate change for soil erosion. A modeling study of Tualatin River basin in Oregon indicated increases in winter sediment loading, particularly if urban development continues to increase [15]. However, studies from other regions have shown that declines in spring sediment loading can trump winter increases [16]. For instance, declining snow pack in the Sierra Nevada Mountains of California is expected to reduce sediment by $50 \%$ over the century, due to decreased spring and summer flows [17]. The extent to which warming alone, without long-term changes in precipitation, alters sediment loading, is basin specific [18], and also likely elevation dependent [6]. While a number of modeling studies suggest sensitivity of sediment loading to warming by itself [18] [19], at least one study from the California Central Valley indicated that sediment losses were much more sensitive to changes in precipitation than to increasing temperature [20].

In this study, we have employed the SWAT model [21] [22] [23] to investigate potential future interactions of climate, agriculture, and environment in the Willamette Valley. The SWAT model is particularly well-suited for simulating the hydrological impacts of diverse agricultural practices [11] [24] [25] [26]. The Willamette Valley has a favorable climate for producing a wide variety of high-yielding crops, and extensive surveys over the last 15 years have provided remotely-sensed identification of 57 major landuse categories, including 39 agricultural landuses [27] [28] [29] [30] [31]. We used an ensemble of regionally-downscaled models from the Coupled Model Intercomparison Project 5 (CMIP5) "high $\mathrm{CO}_{2}$ emissions" (RCP8.5) scenario [32] [33] [34] [35] [36] to provide a diverse, robust set of temperature and precipitation forecasts to simulate impacts on soil erosion and crop production under current landuse conditions throughout the remainder of the 21 st century.

Specific objectives of our research were to evaluate climate impacts on the magnitude, timing, and geographical distribution of soil erosion, identify possible linkages between snowfall and sediment yield, and evaluate how productivity of the Willamette Valley's most abundant crops and other vegetation types may respond to projected climate change. Output from SWAT has been organized into a variety of display formats to facilitate answering of questions common in the climate change arena, including time frames within which certain developments may become apparent, magnitude of potential changes relative to current conditions, and possibilities for non-linear system behavior (i.e., irreversible "tipping points").

\section{Materials and Methods}

\subsection{Watershed Delineation}

ArcSWAT was used to create a hydrologic network of streams and sub-basins 
based on digital elevation model data, predefined boundaries for the entire watershed, and target size for sub-basins, producing a total of 269 sub-basins with a single basin outlet at the Morrison Avenue Bridge in Portland, Oregon. USGS river gauging station $14,211,720$ at that location $\left(45.5178{ }^{\circ} \mathrm{N}\right.$ by $\left.-122.6687^{\circ} \mathrm{W}\right)$ has been functioning since October 1, 1972 (Figure 1). Landuses in the Willamette Valley include a large number of cropping systems, several forest and range types, and urban development. Therefore, subdivision of our area of interest into 269 sub-basins represented a compromise between desires to limit the size of individual sub-basins to ensure homogeneity of landuses in each (which has proven important for simulating sediment loading [37]) versus computer programming constraints involving simulation run times and output file sizes.

\subsection{Landuse and Soils Definition}

For landuse data we modified 11 years of 57-category remote sensing classifications into a single raster mimicking the average percentages over the period from 2004 to 2014 of each landuse category in the entire study area [27] [29] [30] [31]. Pixels were assigned values in a hierarchical manner, favoring classes most commonly present at each position while matching average frequencies for the entire area. The final representative landuse raster contained only 36 classes, having omitted classes that occurred for only a single year at a time or that occurred on less than $2 \%$ of land area within sub-basins. Each unique landuse by soil type combination in each sub-basin defined a hydrologic response unit (HRU), for a total 3790 HRUs in the finished SWAT model. The 33 soil types in our area of interest came from the STATSGO2 data supplied with ArcSWAT.

Some of the 36 landuse classes in the 11-year representative raster closely matched preexisting landuse categories within SWAT, while others (such as Douglas fir as a modification of loblolly pine) had to be created through copying and modification of entries in SWAT's Land Cover/Plant Growth database (Table 1). Operations in the Crop Management table for many crops in the 36 landuse classes were modified to produce more realistic seasonal growth patterns and total annual yields under existing weather conditions. Except for the 10 crops listed in Table 1 as having revised management operations, all others were grown using SWAT defaults for heat unit scheduling and auto-fertilization. The "harvest only" at $80 \%$ efficiency in removing above-ground biomass and "harvest/kill" operations in SWAT were scheduled to produce normal biomass yields and reasonable periods of time with and without ground cover.

\subsection{Weather Data}

Daily weather data required by SWAT were obtained from two sources. To calibrate SWAT for water flow we used daily temperature and precipitation from the Parameter-elevation Regressions on Independent Slopes Model (PRISM) data product for western Oregon for 1981-1995 [38]. To predict future changes we used ten regionally-downscaled models from CIMP5 simulating the representative concentration pathway 8.5 (RCP8.5) high-emissions (business as usual) 


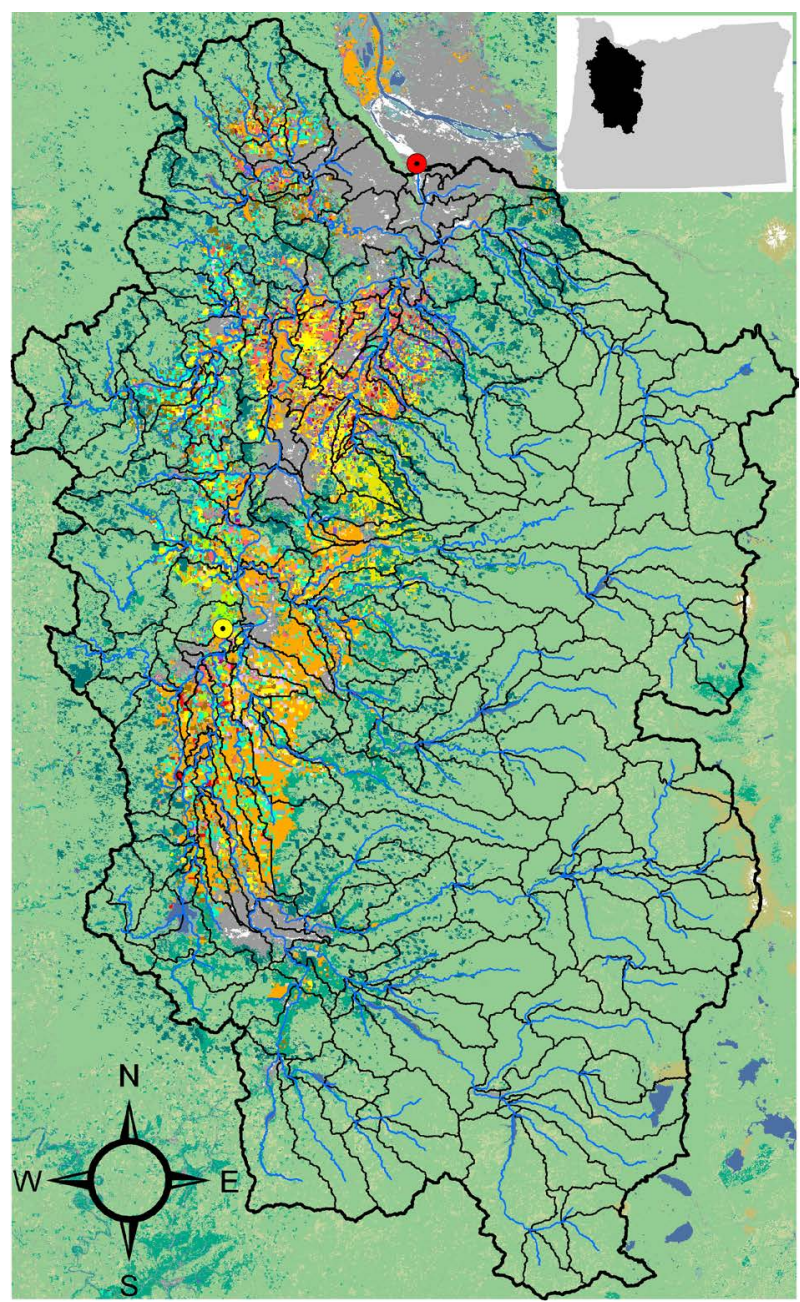

Figure 1. Stream network (blue), sub-basin boundaries (thin black lines), entire Willamette River Basin (heavy black line), representative landuse classifications by plurality-rule over time \{various colors, including forests (light green), annual crops with bare ground in early fall (orange), and urban development (grey), adapted from data published in [27] and [30]\}, and positions of the basin outlet (Morrison Ave. Bridge, red) and the Hyslop weather station (yellow). Inset shows location of the study area within the state of Oregon. Scale is $1: 975,000$ for $279.4 \mathrm{~mm}$ high display. UTM $10 \mathrm{~N}$ projection.

scenario for the period 2010-2099 [32] [33] [36]. PRISM daily precipitation, minimum temperature, and maximum temperature at $4 \mathrm{~km}$ resolution were downloaded for the continental U.S. from the PRISM website

(http://prism.oregonstate.edu/recent/), clipped to our study area, and reprojected to a common coordinate system. The ten climate models were selected from the larger CMIP5 ensemble because they encompassed the full spread in temperature and precipitation anomalies predicted for the PNW. All 10 of the chosen models predicted increases in temperature for western Oregon over time, and most also predicted increased precipitation (Figure 2). Within the general changes over time, three apparent groupings occurred: CanESM2, BNU-ESM, and 
Table 1. Modifications to SWAT land cover/plant growth and crop management databases.

\begin{tabular}{|c|c|c|}
\hline Crop $^{a}$ & $\begin{array}{l}\text { Plant growth parameter } \\
\text { changes from initial values }\end{array}$ & $\begin{array}{l}\text { Crop management operations } \\
\text { replacing any initial settings }\end{array}$ \\
\hline $\begin{array}{l}\text { Douglas fir (DFLL) } \\
\text { modified from FRSE }\end{array}$ & $\begin{array}{l}\text { T_OPT(C) from } 30.0 \text { to } 21.1 \\
\text { CHTMX(m) from } 10 \text { to } 20 \\
\text { BLAI from } 5 \text { to } 8 \\
\text { BIO_E from } 15 \text { to } 24 \\
\text { BIOEHI from } 16 \text { to } 27 \\
\text { WAVP from } 8 \text { to } 7 \\
\text { CO2HI from } 660 \text { to } 600 \\
\text { GSI from } 0.002 \text { to } 0.0018 \\
\text { MAT_YRS from } 30 \text { to } 80 \\
\text { BMX_TREES from } 1000 \text { to } 220 \\
\text { LAIMX1 from } 0.7 \text { to } 0.85 \\
\text { RDMX from } 3.5 \text { to } 1.5 \\
\text { BIO_LEAF from } 0.3 \text { to } 0.15 \\
\text { ALAI_MIN from } 0.75 \text { to } 0.85\end{array}$ & $\begin{array}{l}\text { Plant on Jan. } 1 \\
\text { Harvest only at } 0.8 \text { efficiency on Dec. } 31\end{array}$ \\
\hline $\begin{array}{l}\text { Winter fallow/ } \\
\text { unknown summer crop } \\
\text { modified from EGGP }\end{array}$ & $--^{a}$ & $\begin{array}{l}\text { Plant on Aug. } 1 \\
\text { Harvest/kill on Aug. } 2 \\
\text { No fertilizer applications }\end{array}$ \\
\hline $\begin{array}{l}\text { Spring-plant grass seed } \\
\text { (SPGS) modified from } \\
\text { FESC }\end{array}$ & --- & $\begin{array}{l}\text { Plant on June } 15 \\
\text { Fertilize } 18-46-0 \text { at } 249 \text { ( } 0.5 \text { surf.) } \\
\text { on June } 15 \\
\text { Harvest/kill on Oct. } 15\end{array}$ \\
\hline $\begin{array}{c}\text { Annual or perennial } \\
\text { ryegrass grown for seed } \\
\text { (LOLP) modified from } \\
\text { RYEG }\end{array}$ & --- & $\begin{array}{l}\text { Plant on Jan. } 1 \\
\text { Fertilize } 46-0-0 \text { at } 244 \text { on Mar. } 1 \\
\text { Fertilize } 46-0-0 \text { at } 122 \text { on Apr. } 1 \\
\text { Harvest/kill on July } 5 \\
\text { Plant on Sept. } 15 \\
\text { Fertilize } 46-0-0 \text { at } 49 \text { on Oct. } 1 \\
\text { Harvest/kill on Dec. } 31\end{array}$ \\
\hline $\begin{array}{l}\text { Orchardgrass grown for } \\
\text { seed (DACG) modified } \\
\text { from BLUG }\end{array}$ & --- & $\begin{array}{l}\text { Plant on Jan. } 1 \\
\text { Fertilize } 46-0-0 \text { at } 227 \text { on Mar. } 1 \\
\text { Fertilize } 46-0-0 \text { at } 114 \text { on Apr. } 1 \\
\text { Harvest only at } 0.8 \text { efficiency on June } 25 \\
\text { Fertilize } 46-0-0 \text { at } 98 \text { on Oct. } 1\end{array}$ \\
\hline $\begin{array}{l}\text { Tall fescue grown for } \\
\text { seed modified from } \\
\text { FESC }\end{array}$ & --- & $\begin{array}{l}\text { Plant on Jan. } 1 \\
\text { Fertilize } 46-0-0 \text { at } 227 \text { on Mar. } 1 \\
\text { Fertilize } 46-0-0 \text { at } 114 \text { on Apr. } 1 \\
\text { Harvest only at } 0.8 \text { efficiency on July } 5 \\
\text { Fertilize } 46-0-0 \text { at } 98 \text { on Oct. } 1\end{array}$ \\
\hline $\begin{array}{c}\text { Tall fescue pasture } \\
\text { (TFPA) modified from } \\
\text { FESC }\end{array}$ & --- & $\begin{array}{l}\text { Plant on Jan. } 1 \\
\text { Fertilize } 46-0-0 \text { at } 114 \text { on Apr. } 1 \\
\text { Harvest only at } 0.8 \text { efficiency on May } 1 \\
\text { Fertilize } 46-0-0 \text { at } 114 \text { on June } 15 \\
\text { Harvest only at } 0.8 \text { efficiency on Aug. } 1 \\
\text { Harvest/kill Dec. } 31\end{array}$ \\
\hline $\begin{array}{c}\text { Tall fescue hay crop } \\
\text { (TFHY) modified from } \\
\text { FESC }\end{array}$ & --- & $\begin{array}{l}\text { Plant on Jan. } 1 \\
\text { Fertilize } 46-0-0 \text { at } 114 \text { on Apr. } 1 \\
\text { Harvest only at } 0.8 \text { efficiency on May } 1 \\
\text { Fertilize } 46-0-0 \text { at } 114 \text { on June } 15 \\
\text { Harvest only at } 0.8 \text { efficiency on Aug. } 1 \\
\text { Harvest/kill Dec. } 31\end{array}$ \\
\hline
\end{tabular}




\begin{tabular}{|c|c|c|}
\hline Continued & & \\
\hline $\begin{array}{l}\text { Fall-plant clover (FPCL) } \\
\text { modified from CLVR }\end{array}$ & --- & $\begin{array}{l}\text { Plant on Mar. } 1 \\
\text { Harvest/kill on Oct. } 1\end{array}$ \\
\hline $\begin{array}{l}\text { Winter wheat } \\
\text { modified from WWHT }\end{array}$ & --- & $\begin{array}{l}\text { Plant on Jan. } 1 \\
\text { Fertilize } 46-0-0 \text { at } 146 \text { on Feb. } 14 \\
\text { Fertilize } 46-0-0 \text { at } 243 \text { on Mar. } 15 \\
\text { Harvest only at } 0.8 \text { efficiency on Aug. } 1\end{array}$ \\
\hline Hops equated to COFF & --- & --- \\
\hline $\begin{array}{c}\text { Bentgrass equated } \\
\text { to TIMO }\end{array}$ & --- & --- \\
\hline $\begin{array}{l}\text { Fine fescue equated } \\
\text { to BLUG }\end{array}$ & -- & --- \\
\hline
\end{tabular}

${ }^{\mathrm{a}}$ Growth parameters or management operations of initial SWAT crops were unchanged.

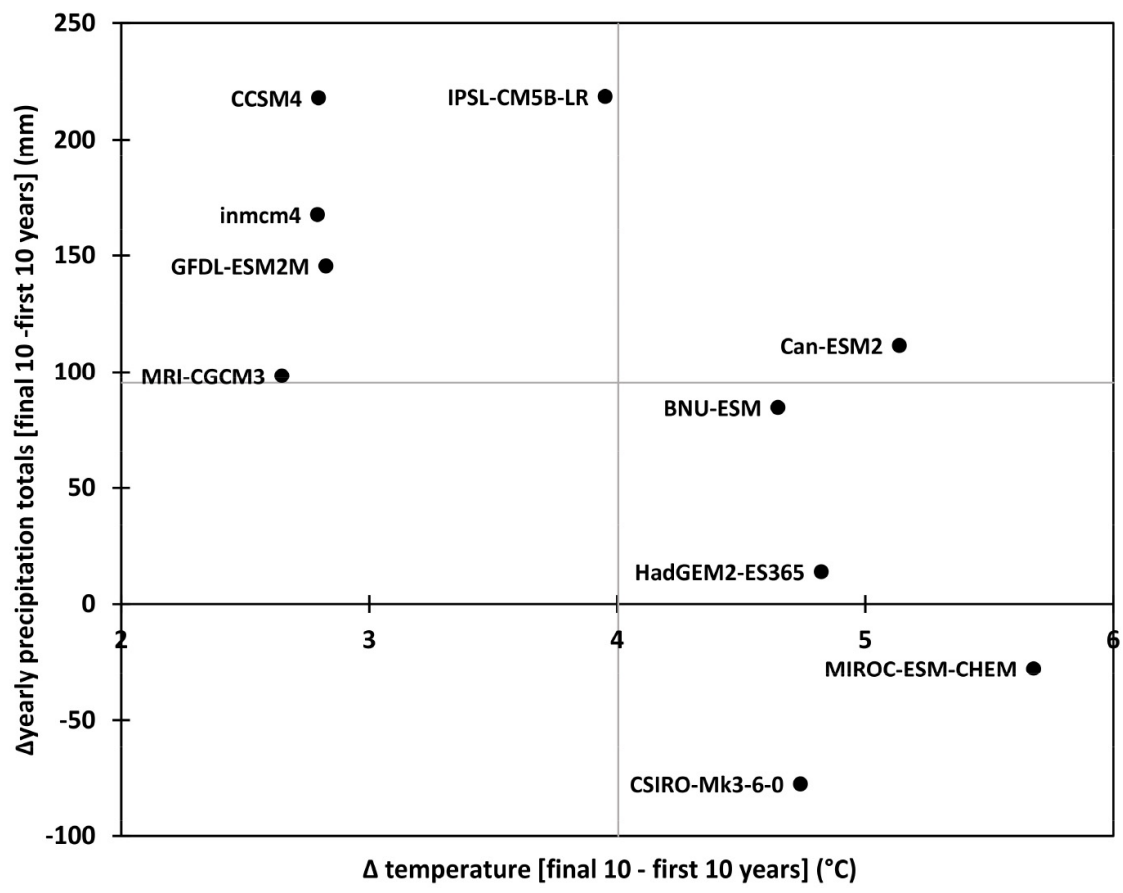

Figure 2. Delta precipitation versus delta temperature for 10 climate models as means of the final 10 minus the first 10 years.

HadGem2-ES365 were relatively warm and wet, MIROC-ESM-CHEM, and CSIRO-Mk3-6-0 were relatively warm and dry, and the remaining five models were relatively wet but not as warm. Temperature and precipitation data were downscaled from $1.4^{\circ}$ general circulation model (GCM) grids to $2.5^{\prime}(4 \mathrm{~km})$ cells using the MACAv.2 method [32], and downloaded from the CMIP5 MACA website (http://maca.northwestknowledge.net/) for the minimally-sized rectangle covering the Willamette River Basin. Python scripts automated the process of averaging values of all pixels within each of the 269 sub-basins, with an intermediate conversion of spatial raster data into defined-order, non-spatial arrays to improve processing speed. The first four years were omitted from reporting in all climate models to allow internal SWAT waters to rage tables to equilibrate, leaving 90 years of useful runs for each model. The first two years of PRISM data 
were similarly omitted from reports. The precipitation versus temperature climate-space of the complete 90-year record (Figure 3) has annual rainfall totals falling between 757 and $2906 \mathrm{~mm}$, and annual mean temperatures falling between $9.65^{\circ} \mathrm{C}$ and $18.79^{\circ} \mathrm{C}$. By comparison, the $1985-2010$ calibration PRISM data fell between 1043 and $2334 \mathrm{~mm}$ for rainfall and between $9.21^{\circ} \mathrm{C}$ and $15.63^{\circ} \mathrm{C}$ for temperature. To further characterize the longer historical temperature record, we also compiled tabular summaries of direct observations from the Hyslop Cooperative Weather Station 351,862 near Corvallis, OR, for the period 1948-2015 (Table 2). Weather data for Hyslop were downloaded from the National Oceanic and Atmospheric Administration

(http://www.ncdc.noaa.gov/cdo-web/datasets/ANNUAL/locations/CITY:US410 004/detail).

\subsection{Hydrologic Calibration}

Nash-Sutcliffe Efficiency (NSE) [39] [40] values were computed for results from SWAT runs of "water years" (defined as going from Oct. 1 of the previous calendar year through Sept. 30 of the current year) for 1985 through 1993 using 4-km resolution PRISM data for temperature and precipitation averaged over each of the 269 sub-basins versus observed flow at the outlet in Portland, OR (https://waterdata.usgs.gov/or/nwis/inventory/?site_no=14211720). NSE values were computed for daily, weekly, and monthly periods, and SWAT was calibrated to the Willamette River Basin by adjusting five individual parameters

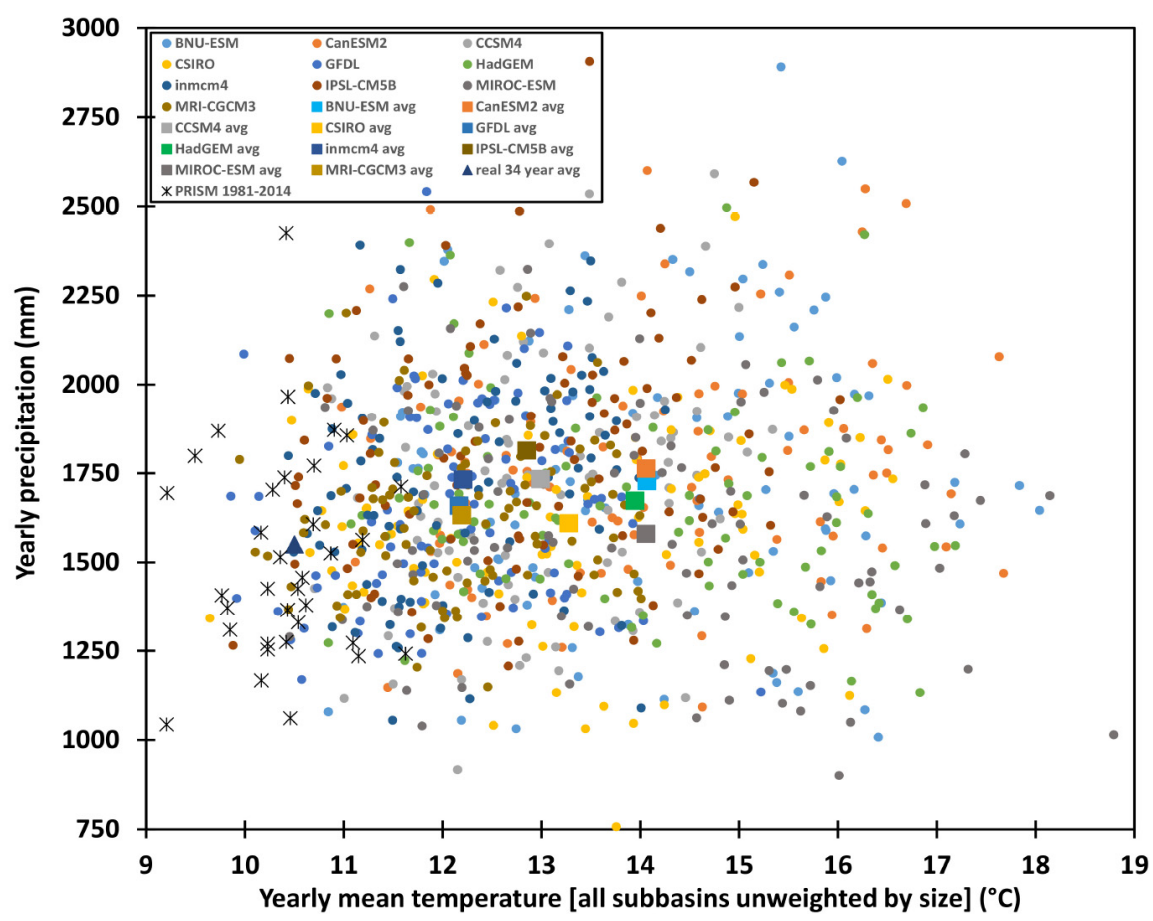

Figure 3. Yearly precipitation versus temperature for 10 climate models run from 2010 to 2099 (small colored disks). Large square symbols are means of each climate model. PRISM weather data from 1981 to 2014 (asterisks) averaged $1550 \mathrm{~mm}$ precipitation and $10.5^{\circ} \mathrm{C}$ temperature (triangle). 
Table 2. Mean precipitation and temperature values at the Hyslop Cooperative Weather Station 351862 as monthly averages over the period from July 1948 to February 2015.

\begin{tabular}{ccccc}
\hline \multirow{2}{*}{ Month } & $\begin{array}{c}\text { Precipitation } \\
\text { totals }\end{array}$ & \multicolumn{2}{c}{ Monthly means of daily temperature extremes } \\
\cline { 3 - 5 } & $(\mathrm{mm})$ & Highs & Lows & Averages \\
\hline January & 173.2 & 7.7 & 0.8 & 4.2 \\
January & 173.2 & 7.7 & 0.8 & 4.2 \\
February & 127.9 & 10.4 & 1.7 & 6.0 \\
March & 118.3 & 12.8 & 2.8 & 7.8 \\
April & 67.7 & 15.7 & 4.2 & 9.9 \\
May & 54.4 & 19.4 & 6.6 & 13.0 \\
June & 34.1 & 22.8 & 9.2 & 16.0 \\
July & 10.3 & 27.3 & 10.8 & 19.1 \\
August & 15.9 & 27.6 & 10.7 & 19.1 \\
September & 36.2 & 24.7 & 8.9 & 16.8 \\
October & 84.1 & 18.0 & 5.5 & 11.8 \\
November & 164.9 & 11.4 & 3.2 & 7.3 \\
December & 191.3 & 7.9 & 1.2 & 4.6 \\
Annual precipitation & & 17.2 & 5.5 & \\
total and temperature & 1078.1 & & & \\
means over 66 yr 8 mo & & & & \\
\hline
\end{tabular}

(described below) until no further improvement in NSE was seen. Test water years were randomly selected as 1988, 1989, 1990, 1992, and 1993, with validation years of 1985, 1986, 1987, and 1991. In addition to the normal method for calculating NSE, we also computed values with SWAT data from earlier or later in time over a range of several days relative to the river gauge readings. Parameters calibrated during the 45 SWAT runs included: 1) Hargreaves versus Penman-Montieth calculation of potential evaporation/transpiration (PET), 2) ground water delay (GW_DELAY), 3) soil evaporation compensation factor (ESCO), 4) curve number (CN2), and 5) soil erodibility (Soil K). After all of these parameters had been optimized, we cycled through them again in the same order to test for any sensitivity to changes that had been made to the other parameters after initial optimization. We deliberately excluded reservoirs from our hydrologic model because their operation was both complex and opaque, involving combinations of short-term flood control, long-term storage, and legally mandated, temporally-varying adjustments for the benefit of fish [41]. Problems associated with attempts to include sediment yield in the calibration process are discussed below.

\subsection{General Conditions of Study Area}

The Hyslop Field Laboratory Cooperative Weather Station, located $10 \mathrm{~km}$ NE of 
Corvallis, Oregon, at $70 \mathrm{~m}$ above sea level (masl), represented the climate experienced by most (lower elevation) Willamette Valley farms and ranches. Long-term average daily high, low, and mean temperatures of $17.2^{\circ} \mathrm{C}, 5.5^{\circ} \mathrm{C}$, $11.3^{\circ} \mathrm{C}$ have combined with average annual precipitation totals of $1078 \mathrm{~mm}$ (Table 2) to produce an environment currently well-suited to production of a variety of rain-fed crops, including winter wheat, perennial and annual cool season grasses grown for seed, and pasture and hay as feed for livestock, in addition to a multitude of irrigated crops [42] [43]. The modified-maritime climate experiences nearly $80 \%$ of its annual precipitation in the period from October through March, during which time average daily high and low temperatures of $11.4^{\circ} \mathrm{C}$ and $2.5^{\circ} \mathrm{C}$ allow continued growth of many plants, particularly cool season grasses and conifers. Limited precipitation during the period of June through September combines with average daily high temperatures of $25.6^{\circ} \mathrm{C}$ to provide reliable harvest conditions for wheat and grass seed crops, while also creating moisture stress that limits productivity of rain-fed annual and perennial crops and natural ecosystems. Lower temperatures and greater precipitation at higher elevations result in basin-wide averages for the PRISM data that differ somewhat from Hyslop. For the 1981-2010 period, PRISM data averaged $1.48^{\circ} \mathrm{C}$ and $0.83^{\circ} \mathrm{C}$ lower than the Hyslop weather station data for daily high and low temperatures, respectively, along with $429 \mathrm{~mm} \cdot \mathrm{y}^{-1}$, or $39.6 \%$, greater precipitation.

\section{Results and Discussion}

\subsection{Hydrologic Calibration of SWAT}

SWAT model runs using the default set of parameters (i.e., those initially calibrated by SWAT's programmers for use on any generic set of watersheds) performed poorly, with average NSE for daily discharge at Portland negative in both test and validation years (Table 3). Numerous flood control structures were built on the Willamette River and its tributaries by the U.S. Army Corp of Engineers in the period from 1941 to 1969 [41], with a complex set of regulations governing the retention/release of water to control flooding, benefit fish, and support irrigation. Because we did not explicitly model any of these activities, it was not surprising that daily flows were poorly modeled. NSE for discharge modeled over weekly and monthly periods averaged 0.390 and 0.682 in the five test water years, with performance slightly better in the other four water years set aside for validation use. Discrepancies in NSE among daily, weekly, and monthly time periods suggested the likely existence of a brief time-delay factor in flow of water through the watershed, one that would need to be accounted for during basin-specific calibration. Recalculating NSE values using small temporal offsets gave considerable improvement when flows predicted by SWAT for one to two days earlier than the actual discharge measurements at the Morrison Avenue Bridge were used (e.g., SWAT prediction for Feb. 1 compared to observed flow on Feb. 2 or Feb. 3). This improvement in NSE with one or two day offsets 
Table 3. Average daily, weekly, and monthly NSE values before and after calibration of SWAT to local conditions.

\begin{tabular}{ccccc}
\hline & \multicolumn{2}{c}{$\begin{array}{c}\text { Default SWAT } \\
\text { parameters }\end{array}$} & $\begin{array}{c}\text { SWAT following } 45 \text { cycles }^{2} \\
\text { of localized calibration }\end{array}$ \\
\cline { 2 - 5 } Time period & Test years & $\begin{array}{c}\text { Validation } \\
\text { years }\end{array}$ & Test years & $\begin{array}{c}\text { Validation } \\
\text { years }\end{array}$ \\
\hline Daily (no offset) & -0.763 & -0.390 & 0.270 & 0.434 \\
Daily (using 1 day earlier SWAT) & -0.599 & -0.179 & 0.387 & 0.536 \\
Daily (using 2 day earlier SWAT) & -0.544 & -0.189 & 0.399 & 0.514 \\
Weekly (no offset) & 0.390 & 0.529 & 0.729 & 0.773 \\
Weekly (using 2 days earlier SWAT) & 0.588 & 0.654 & 0.864 & 0.880 \\
Monthly (no offset) & 0.682 & 0.750 & 0.897 & 0.890 \\
\hline
\end{tabular}

${ }^{a}$ Calibration changes: PET from Penman-Montieth to Hargreaves method, GW_DELAY from 31 to 270 days, $\mathrm{ESCO}$ as $0.96 \mathrm{X}$ initial values, $\mathrm{CN} 2$ as $0.4 \mathrm{X}$ initial values, and Soil $\mathrm{K}$ as $0.3 \mathrm{Xinitial}$ values.

between SWAT predictions and measurements in Portland was present throughout all 45 rounds of calibration, although the magnitude of the benefit diminished as parameters within SWAT became better calibrated to the localized conditions of the Willamette River Basin.

The single most important calibration change was going from the default Penman-Montieth to the Hargreaves method for calculating potential evapo-transpiration (PET) (Table 3). Without this change to PET, discharge over entire water years was always overestimated throughout the local calibration process, with an initial overestimation of $14.7 \%$ in the case of SWAT run using default parameters averaged over all test and validation years. After the 45 cycles of calibration to localized conditions, average predicted and observed discharge for a combination of all water years agreed to within less than a $0.05 \%$ difference. After PET, the next most important parameter to change was ground water delay, with improvement in NSE noted in all increases from the 31-day default on out to the final value used of 270 days. Ground water delay was the only parameter that needed any substantial further adjustment after the other three parameters (soil evaporation compensation factor [ESCO], USDA-Soil Conservation Service (SCS) "runoff curve number for moisture condition II" [CN2], and SCS "Universal Soil Loss Equation soil erodibility factor" [Soil K] had also been optimized. We interpreted the final 270 day value for ground water delay as representing, at least in part, seasonal redistribution of water provided by the operation of the Army Corp of Engineers reservoirs, although it could indeed also represent actual ground water flow. This nine-month period corresponded to the time between peak rainfall in November through January and minimum streamflow in August through October, with lowering of peaks and raising of troughs by the 270 day ground water delay.

Changes made to ESCO were relatively minor (Table 3 ) and within the range of those often reported in calibrations of SWAT by other researchers [10] [12] [24]. The changes in $\mathrm{CN} 2$ and Soil $\mathrm{K}$ (lowering them to $40 \%$ and $30 \%$ of their 
initial values) were larger than those usually reported in calibrations of SWAT to other localities, but contributed to the overall improvements in NSE that occurred for daily, weekly, and monthly time steps. Weekly NSE values of 0.864 and 0.880 for test and validation years using 2-day offsets were almost as good as the monthly values. Daily NSE with no temporal alignment offset averaged 0.270 in test years and 0.434 in validation years, far better than the general default calibration originally present in SWAT. By the end of hydrologic calibration there was little evidence to differentiate between one and two days for the alignment offset, with results in test years slightly favoring the longer offset with opposite results from validation years. The consistently better NSE in validation than in test years supported our belief that we had not over-calibrated SWAT, and the hydrology should be reliable for a considerable range of temperature and precipitation conditions. Whether or not this reliability extends on out to the very end of the RCP8.5 scenarios in 2099 is unanswerable, but at the very least the locally-calibrated SWAT model should be able to describe those periods of time within which the future remains relatively similar to the recent past. Possible criteria for defining the end of similarity might include excursions outside the temperature and precipitation ranges present in the weather used in calibration and/or the occurrence of highly unusual levels of predicted sediment yield or biomass productivity.

Average predicted sediment yield in the period used to calibrate water flow in SWAT (1985 to 1993) decreased from 4.36 MT.ha-1 before local hydrologic calibration to $2.37 \mathrm{MT} \cdot \mathrm{ha}^{-1}$ after calibration. Whether or not this $46 \%$ reduction in apparent upland soil erosion plus streambank failure improved SWAT's fit with current conditions was tested by examining available data on total suspended solids (TSS) present in rivers within the Willamette River Basin. Gravimetrically measured TSS data were sparse, with a total of only 54 individual-day measurements at the Morrison Avenue river gauge over the entire nine years used for calibration (Chauncey Anderson, USGS, Portland, OR, personal communication). Only seven of these cases corresponded to days on which SWAT predicted sediment yields of $0.01 \mathrm{MT} \cdot \mathrm{ha}^{-1}$ or more. While nephelometric measurements of turbidity at Morrison Avenue are extensive, their conversion into absolute TSS would be complicated by changes in instrumentation over time, the necessity for adequate numbers of TSS values corresponding to the daily turbidity measurements, and misalignment between periods covered by given instruments and the particular weather records used to calibrate SWAT and initialize CIMP5. TSS from USDA-ARS sampling of water quality for subbasins on the Calapooia River [28], whose confluence with the Willamette River lies $6.5 \mathrm{~km}$ east of the Hyslop Weather Station, provided a total of 142 usable samples from four different sites corresponding to subbasin outlets in the SWAT hydrologic network. Using the more detailed reporting present in the daily SWAT output for the full set of all 269 individual subbasins, the locally calibrated SWAT model over-predicted sediment yield in only $1 / 6^{\text {th }}$ of cases, while under-predicting it in the other $5 / 6^{\text {th }}$ of cases. However, the relatively infrequent over-predictions were themselves suffi- 
ciently large that the average SWAT sediment yield was $4.97 \times$ the size of the average in-stream measurement for the Calapooia River. Procedures used to obtain water quality samples for the Calapooia River were biased against the more extreme rainfall events by general infrequency of sampling (only once every month) combined with inability to reach sampling sites during floods. Hence, the TSS observations came from days tending to miss the largest rainfall and soil erosion events. The possibility of also calibrating SWAT for sediment yield, in addition to water yield, was therefore dismissed due to the sparseness of data and the available data's bias against the very conditions of greatest interest.

A recent calibration of the USGS SPARROW model to western Oregon and northwestern California was recognized as substantially under-predicting suspended-sediment transport relative to historical data for periods from 1950 through 1973, largely due to bias against high intensity precipitation and soil erosion events in the 1992 through 2012 routine sampling data used for SPARROW's calibration [44] [45]. While SPARROW's inclusion of 68 sampling sites broadened its spatial extent, its ultimate selection of the extremely coarse yearly time-scale for summarizing water flow and sediment yield, in contrast to the more desirable range of daily to weekly calculations in SWAT, essentially excluded it from the possibility of usefully modeling the impact of climate change on sediment yield. Our own inability to include sediment yield in calibration of SWAT left us with the conclusion that our hydrology-only calibration process likely provided some marginal improvement in the accuracy of SWAT's sediment yield predictions for weather conditions present from 1985 through 1993. Simultaneous calibration of both water yield and sediment yield in SWAT would increase confidence in the quantitative reliability of sediment yield predictions. However, in order to assume that SWAT was accurately modeling upland soil erosion, stream bank failure, and sediment transport in altered climatic conditions of the future, it would be critical to collect extensive, unbiased data on TSS during the most extreme storm events currently occurring. Collection of such data and their use in converting daily turbidity measurements into TSS is a worthy endeavor well beyond the scope of the research being reported in this manuscript.

\subsection{Temperature and Precipitation Patterns InCIMP5 Models}

The CIMP5 models of the RCP8.5 scenario produced a wide range in precipitation and temperature conditions for the Willamette River Basin. Differences in precipitation versus differences in temperature for each of the climate models were plotted between the final (2090-2099) and first decades (2010-2019) rather than pairs of 20-year periods to minimize change between recent historic conditions and the start of the delta time comparison (Figure 2). Temperature increased from the first to the final decade for all 10 of the models, with an average increase of $4^{\circ} \mathrm{C}$ total or $0.05^{\circ} \mathrm{C} \cdot \mathrm{y}^{-1}$. Precipitation increased from the first to the final decade for eight out of the 10 models, with the average net change for all 10 models being an increase of $1.19 \mathrm{~mm}$ per year, or $95 \mathrm{~mm}$ total $(5.8 \%)$ over the 
entire period. The two wettest models (CCSM4 and IPSL-CM5B-LR) both predicted average annual precipitation gains of $2.7 \mathrm{~mm} \cdot \mathrm{y}^{-1}$, while the driest model (CSIRO-Mk3-6-0) predicted changes in precipitation of $-0.9 \mathrm{~mm} \cdot \mathrm{y}^{-1}$. Ensemble mean values for temperature and precipitation changes served to subdivide Figure 2 into four quadrants, of which two were well occupied, with the models tending to fall into two main clusters. Although temperatures increased over time in all models, the half of them with the highest warming rates were generally drier than the average change over time in precipitation (CanESM2, BNU-ESM, HadGEM2-ES365, MIROC-ESM-CHEM, and CSIRO-Mk3-6-0), while the half with the lowest warming rates were generally wetter than average (inmcm4, GFDL-ESM2M, MRI-CGCM3, CCSM4, and IPSL-CM5B-LR).

Compared to historical weather as represented by PRISM data for the entire Willamette River Basin in the 34 years from 1981 to 2014, the 10 CIMP5 models predicted average temperature increases over the entire period from 2010 to 2099 in a range from $1.7^{\circ} \mathrm{C}$ to $3.6^{\circ} \mathrm{C}$, with a mean of $2.7^{\circ} \mathrm{C}$, and average precipitation increases in a range from $30 \mathrm{~mm}$ to $314 \mathrm{~mm}$, with a mean of $143 \mathrm{~mm}$ or 9.2\% (Figure 3). Defining similarity/dissimilarity between observed and modeled weather on the basis of whether 34 years of annual summaries of real weather data plotted within or outside of non-parametric frontiers of precipitation versus temperature for each of the 10 models revealed that averages of only $40 \%$ of the real weather fell within the two-dimensional clouds of modeled weather. Models with which real weather possessed greatest similarity included CSIRO-Mk3-6-0, GFDL-ESM2M, and IPSL-CM5B-LR at 76.5, 67.6, and 67.6\% overlap, respectively. The most dissimilar cases were CanESM2, BNU-ESM, HadGEM2-ES365, and CCSM4 with only 11.8\%, 14.7\%, 20.6\%, and 23.5\% overlap by the real weather, respectively. Failure of $20.6 \%$ of the real weather to fall within the combined data clouds of all the models suggests the presence within the real weather of certain amount of climate change as warming temperatures over the period from 1981 to 2014, similar to other reports [46] [47]. Climate data from the historical CIMP5 calibration period from 1950 to 2005 for all models possessed nearly identical 56-year averages in precipitation and temperature, although the daily and individual-year average temperature and total precipitation values varied widely among the models. The 56-year means also closely matched those from PRISM for 1981-2014.

\subsection{Effects of Temperature and Precipitation on Sediment Yield}

Average sediment yield for the entire Willamette River Basin at the start of the simulations in 2010 was in a range of 1 to $4 \mathrm{MT} \cdot \mathrm{ha}^{-1}$ (Figure 4), values agreeing with baseline sediment yield averaging 2.37 MT.ha ${ }^{-1}$ during the 1984 to $1993 \mathrm{ca}$ libration period, and with general reports from other sources of measured soil erosion rates within the Willamette River Basin [28] [48] [49]. Simple regressions of area-specific sediment yield versus time for the 10 climate models produced relatively modest predictions for the first three to four decades of the simulation period, with only slight increases by the 2040s when a majority of 


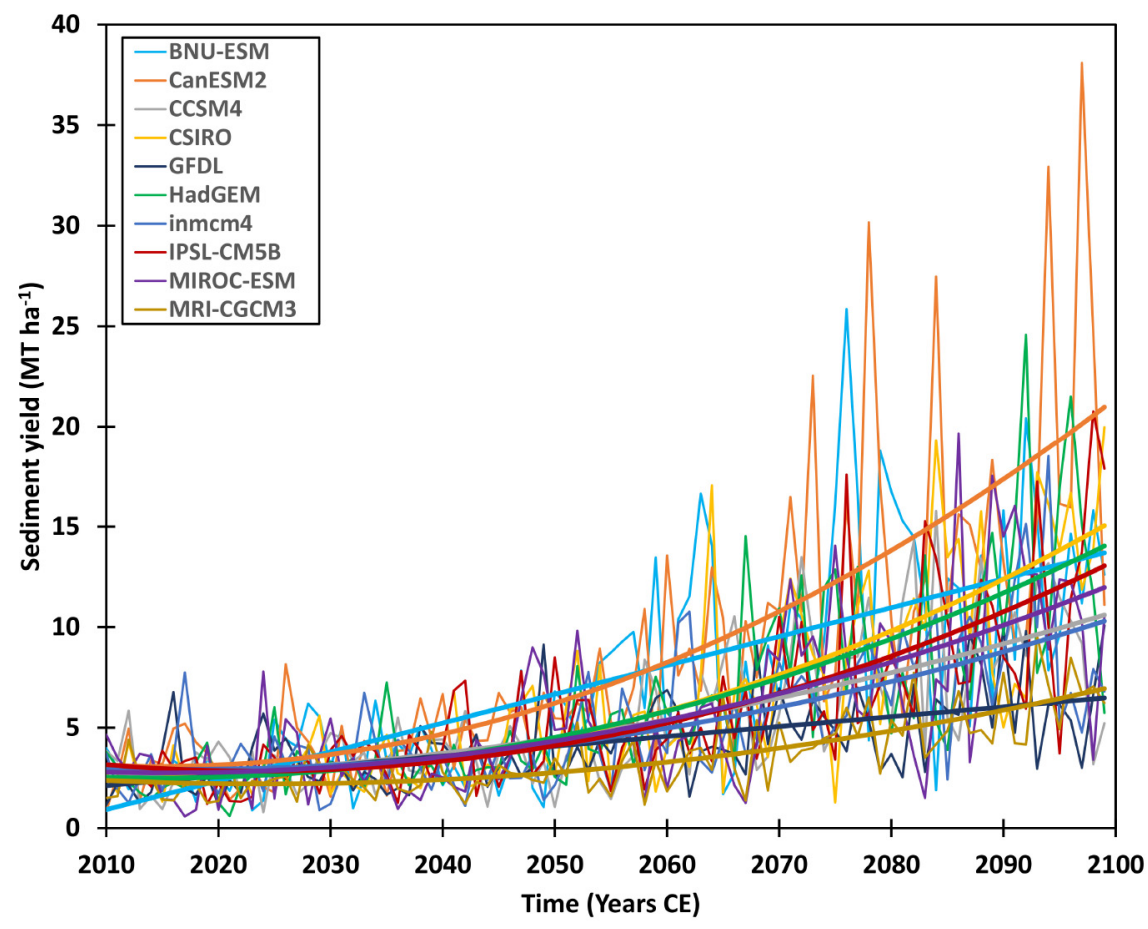

Figure 4. Sediment yield versus time for 10 climate models, two as simple linear and eight as quadratic regressions, with year-to-year changes plotted using thinner lines of the same colors.

predictions still fell within the range of traditional year-to-year variation. From 2050 onward the situation changed, with means and variances of all models progressively increasing over time, while overlap with customary rates of erosion essentially vanished by 2099. For those models predicting the least erosion (MRI-CGCM3 and GFDL-ESM2M), annual sediment yield increased by approximately $200 \%$ to around $7 \mathrm{MT} \cdot \mathrm{ha}^{-1}$ by the final decade of the 21 st century. For the model predicting the greatest erosion (CanESM2), sediment yield increased by an average of $18 \mathrm{MT} \cdot \mathrm{ha}^{-1}$ over baseline for the regression by 2090-2099, with individual yearly data points as high $35 \mathrm{MT} \cdot \mathrm{ha}^{-1}$ over baseline. Such values represented losses of $1.5-2.7 \mathrm{~mm}$ of soil per year, or approximately one to two centuries to strip the productive topsoil from the landscape assuming soil loss was uniformly distributed. The increasing noise in the signal during the second half of the $21^{\text {st }}$ century may represent a warning of potential transition from conditions as we have known them to a more chaotic future with increasing frequency of unusually large sedimentation events. Less rapid warming than under the assumptions of the RCP8.5 scenario might postpone such a transition by decades relative to the timing in Figure 4 .

To more clearly understand factors behind the soil erosion being modeled by SWAT, we plotted the model-average values for changes in sediment loading between final and first decades of the simulations for corresponding values of both temperature (Figure 5) and precipitation (Figure 6). The graph for temperature showed a strong linear trend of increasing sediment loss with increasing 


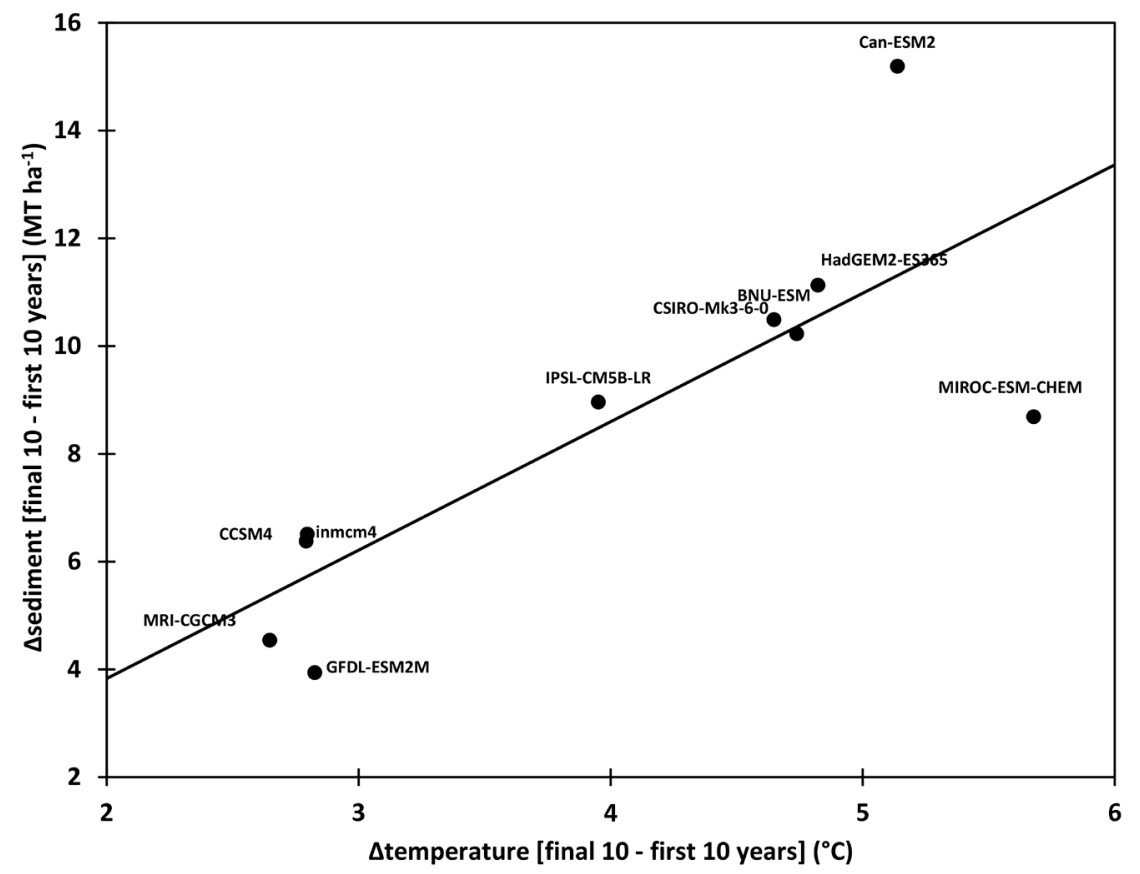

Figure 5. Delta sediment versus delta temperature for 10 climate models as means of the final 10 minus the first 10 years. Black line is the linear regression fit of delta sediment on delta temperature, with correlation $\mathrm{R}=0.8066$.

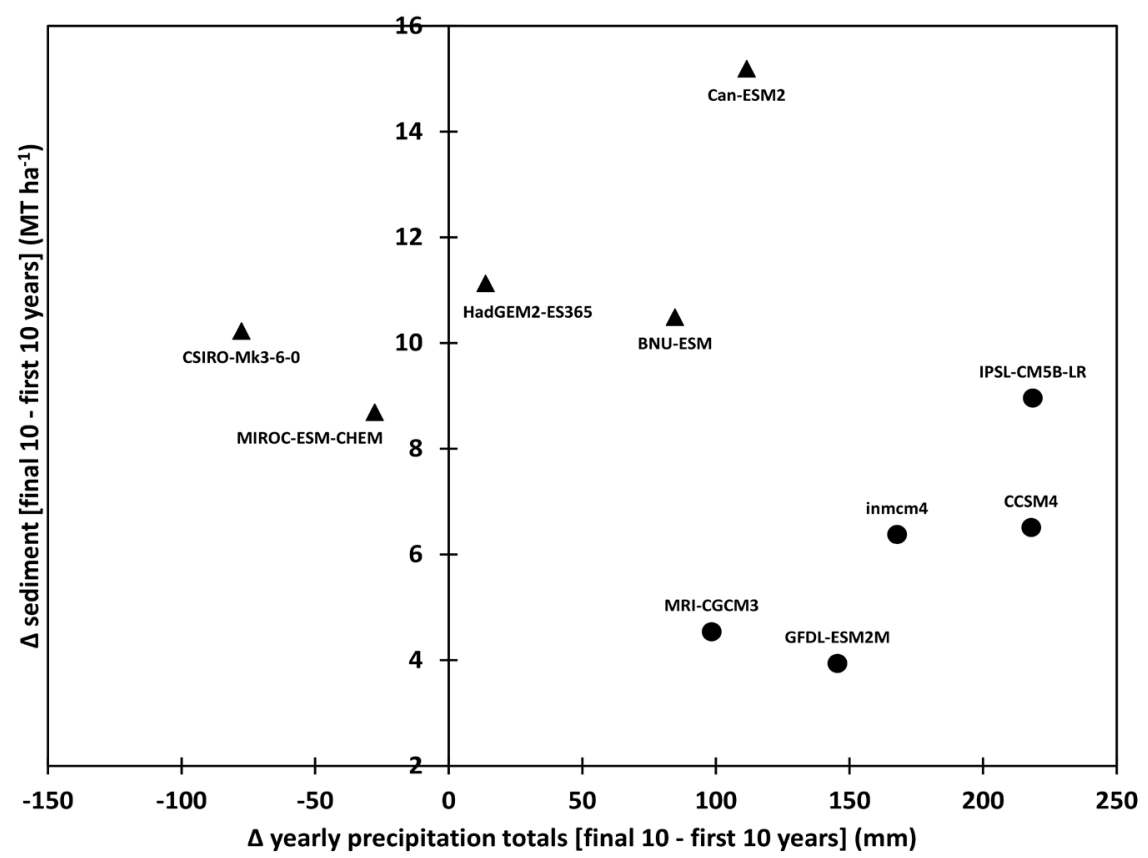

Figure 6. Delta sediment versus delta precipitation for 10 climate models as means of the final 10 minus the first 10 years. Figure 2 model membership in cooler/wetter (triangles) and warmer/drier quadrants (circles).

warming ( $\Delta$ sediment yield $=-0.9369+2.2835 \times \Delta$ temperature, $\mathrm{R}^{2}=0.651, \mathrm{P}<$ $0.005)$ along with two prominent outliers, MIROC-ESM-CHEM and Can-ESM2 (Figure 5). The MIROC-ESM-CHEM model had only average increases in se- 
diment yield despite having the greatest warming for the 80 years between first and last decades, while the Can-ESM2 model had the greatest increases in sediment yield and second greatest increases in temperature. The graph for precipitation showed considerable scatter among the climate models (Figure 6) and no clear trend, suggesting a potentially stronger influence of long-term temperature trends than precipitation trends on sediment losses. However, when the models' membership in either the warmer/drier or cooler/wetter quadrants of Figure 2 was considered, it became apparent that within those two groups of five models each, greater precipitation was quite clearly associated with greater sediment loss.

Altering the perspective from that of net changes over 80 years (Figure 5 and Figure 6) to annual relationships helps to further clarify the impacts of both temperature (Figure 7) and precipitation (Figure 8) on soil erosion. The influence of temperature on erosion was relatively small during the first $2.5^{\circ} \mathrm{C}$ of warming above the starting point of the recent actual basin-wide mean of $10.5^{\circ} \mathrm{C}$, with transition from normal to abnormal conditions occurring over the range from $2.5^{\circ} \mathrm{C}$ to $3.5^{\circ} \mathrm{C}$ above normal (Figure 7). Beyond $14^{\circ} \mathrm{C}$, the data points lost their tendency to cluster, expanding instead into a diffuse cloud possessing a wide range of predicted sediment loss for any given value of modeled temperature.

The corresponding plot of sediment yield versus precipitation had several informative features (Figure 8). First, there was an obvious lower limit to erosion rates across the entire graph, with 252 points falling underneath boundaries arbitrarily set halfway between minimum and median values within each group of points defined by $50-\mathrm{mm}$-wide bands over the range of yearly precipitation totals. Most of the other 648 points plotted substantially above these boundaries, presumably due to some combination of adverse effects of temperature and seasonal distribution patterns of precipitation. The lower limits for sediment versus precipitation essentially represented the "best case" scenario for response of western Oregon landscape to varying quantities of precipitation, with sediment yield increasing from 2.0 MT.ha ${ }^{-1}$ at $1550 \mathrm{~mm}$ annual precipitation to 8.7 $\mathrm{MT} \cdot \mathrm{ha}^{-1}$ at $2500 \mathrm{~mm}$. Similar lower boundaries for sediment yield versus yearly precipitation existed when membership was alternately defined as the coolest $28 \%$ of the points (shown in Figure 8 as cross-marks overlapping the model by year points) or as the snowiest $28 \%$ (those with decadal averages of greater than $68.4 \mathrm{~mm}$ precipitation per year as snowfall [these points not separately identified in Figure 8]). For the 648 points above the sediment-based cutoff levels, $80.6 \%$ of them were above both temperature and snowfall-based membership cutoffs. For the 252 points used to produce the sediment-based plot of erosion minimums, $47.6 \%$ of them were simultaneously below both temperature and snowfall-based membership cutoffs.

A large proportion of the total variability in sediment yield was captured when both temperature and precipitation were simultaneously considered. The simplest regression model capable of capturing most of this variation involved 


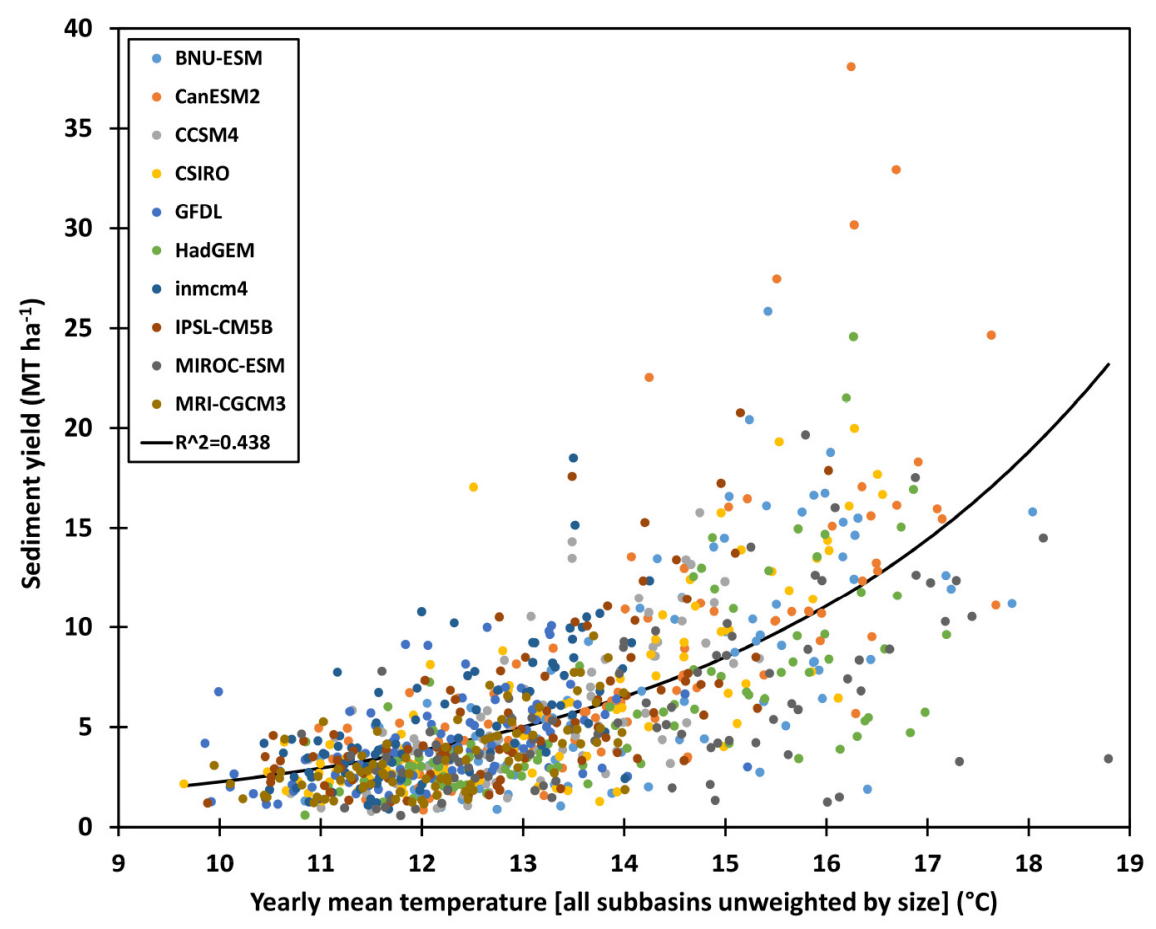

Figure 7. Sediment yield versus mean yearly average temperature for 10 climate models from 2010 to 2099.

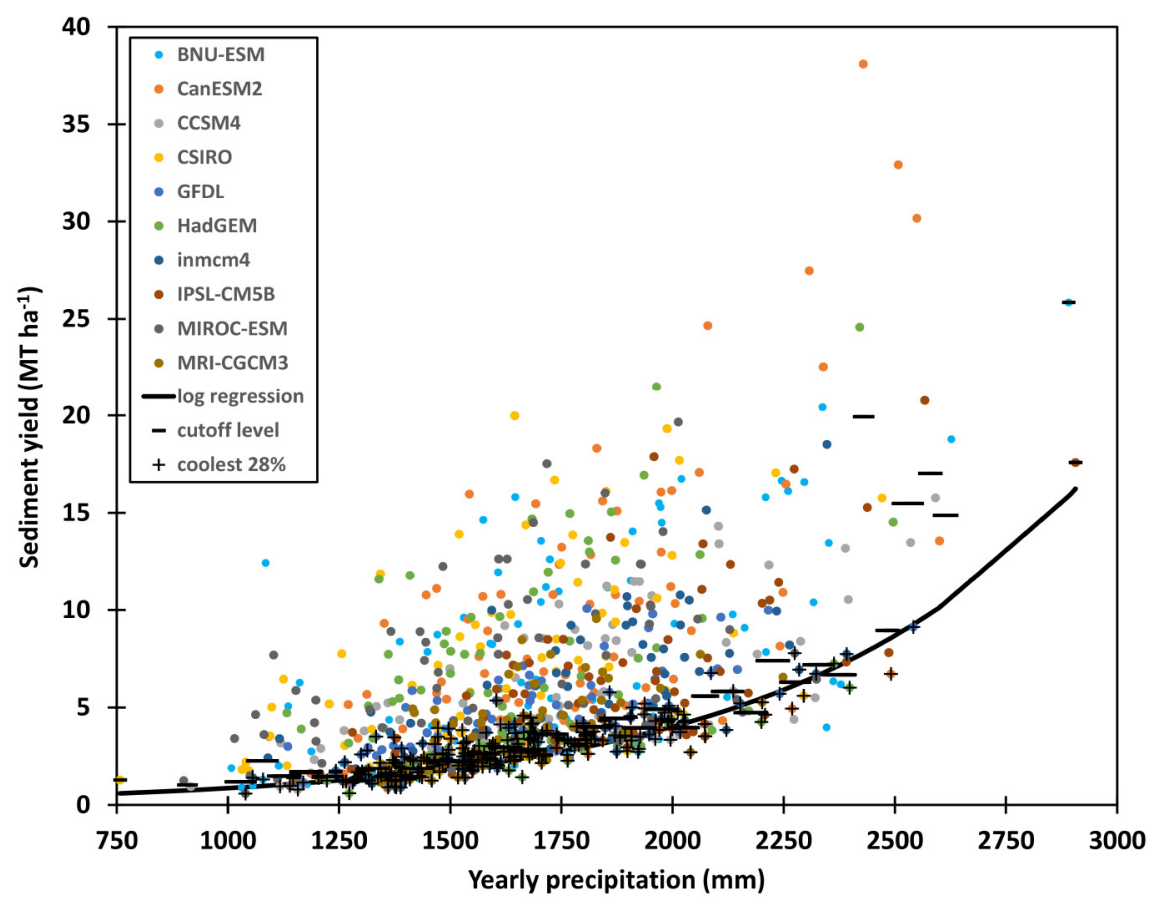

Figure 8. Sediment yield versus mean yearly total precipitation for 10 climate models from 2010 to 2099. Frontier for sediment yield versus precipitation was defined by 252 points below the averages of median and minimum values within 50 -mm-wide precipitation bands, with $\mathrm{R}^{2}$ values of 0.880 and 0.837 for logarithmic regression and detransformed sediment yields. Horizontal black lines denote cutoffs between outliers and points used to define the frontier boundary. Overlapping cross-marks identify the $28 \%$ lowest temperature cases. 
grouping the data into 13 separate temperature bands increasing by $0.5^{\circ} \mathrm{C}$ steps combined with regressing the logarithm of sediment yield on yearly precipitation within each of those bands (Figure 9). This regression model suggested a simple emergent relationship between sediment and climate drivers at an annual timescale. In contrast to the somewhat ambiguous sensitivity to precipitation suggested by Figure 6, annual sediment yields in Figure 9 were highly sensitive to annual precipitation, increasing in an exponential relationship. Warming had the effect of shifting this relationship to produce more sediment for a given amount of precipitation. For instance, at intermediate annual precipitation levels of $1800 \mathrm{~mm}$, each $0.5^{\circ} \mathrm{C}$ of warming increased sediment yield by an average of $13.3 \%$ or approximately $0.9 \mathrm{MT} \cdot \mathrm{ha}^{-1}$. This regression model suggests precipitation differences were responsible for $64.5 \%$ of the differences in annual sediment yield, with temperature differences responsible for $35.5 \%$.

\subsection{Effects of Snow on Sediment Loading}

The increase in sediment yield associated with rising temperatures in Figure 9 was consistent with predictions of more precipitation falling as rain rather than as snow. The relationship between snowfall and soil erosion was examined in detail for all 10 climate models by plotting decade-long averages of sediment yield versus basin-wide precipitation as snowfall (Figure 10). Asymptotic decay functions $\left[\mathrm{Y}=\mathrm{Y}_{\text {asymptote }}{ }^{\star}\left(1 /\left(1-\mathrm{e}^{(- \text {snowfall/K)})}\right)\right]\right.$ were calculated for all 90 data points together and for three separate groups defined by their ranking in the lowest, middle, or highest thirds of total precipitation. Going from a single curve to separate regressions for each of the three precipitation groups increased $R^{2}$ values from 0.558 to 0.731 , with the improvement significant at $\mathrm{P}<0.00001$. The asymptotic decay function described a situation in which basin-wide averages of $70 \mathrm{~mm}$ of precipitation as snow adequately protected soil from erosion, with gradually increasing vulnerability to erosion as snowfall decreased from $70 \mathrm{~mm}$ down to $20 \mathrm{~mm}$ of precipitation equivalent, and extremely high erosion below that level. Snowfall at crucial elevations would obviously be greater than the basin-wide averages that include the typically snow-free valley floor. Curves for sediment yield in the driest and middle thirds of total precipitation were generally similar to each other, with the extra erosion in the middle precipitation group varying from $0.17 \mathrm{MT} \cdot \mathrm{ha}^{-1}$ in cases with $100 \mathrm{~mm}$ of yearly precipitation as snow to $1.87 \mathrm{MT} \cdot \mathrm{ha}^{-1}$ with only $10 \mathrm{~mm}$ precipitation as snow. Sediment yield in the wettest third of decades exceeded that in the driest third by 1.75 and 5.17 $\mathrm{MT} \cdot \mathrm{ha}^{-1}$ in cases with 100 and $10 \mathrm{~mm}$ of yearly precipitation as snow, respectively.

\subsection{Monthly Distribution Patterns of Sediment Loading}

Monthly patterns of sediment yield strongly reflected the seasonal distribution of precipitation and temperature. Over the period from 1984 through 1993, the SWAT model using default parameters predicted that $49 \%$ of the total annual sediment yield would occur in the period from February through April (Table 4). 


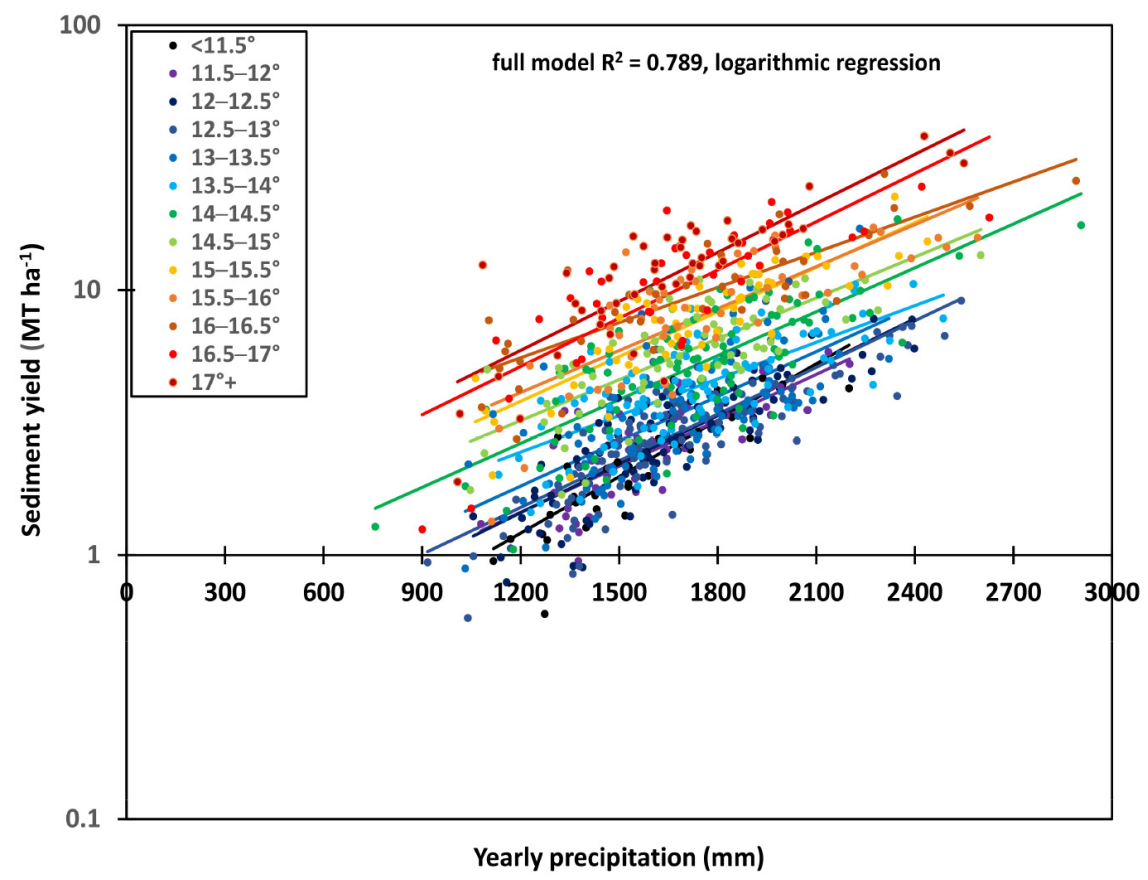

Figure 9. Sediment yield versus mean yearly total precipitation for pooled climate model data regrouped into $0.5^{\circ} \mathrm{C}$ temperature bands. Solid lines plot regressions of log sediment yield versus precipitation within each temperature band, labeled by average temperature. Colored points are identified by their temperature ranges.

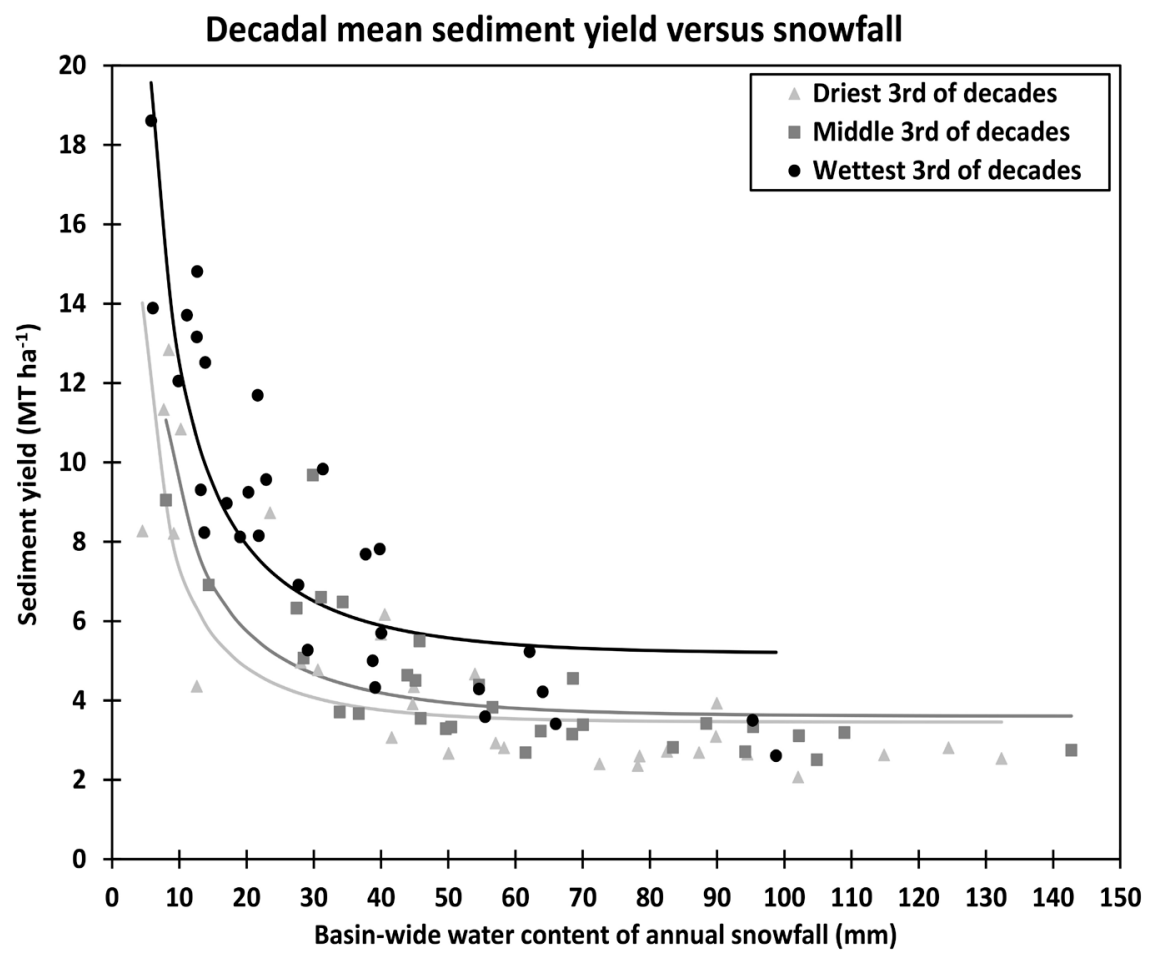

Figure 10. Decade-long average sediment yield versus snowfall for pooled climate model data regrouped into driest, middle, and wettest thirds of precipitation totals, with full model $\mathrm{R}^{2}$ value of 0.763 and individual precipitation group $\mathrm{R}^{2}$ values of $0.546,0.480$, and 0.768 , respectively. 
Table 4. Monthly patterns of sediment yield for 10-year averages of selected models.

\begin{tabular}{ccccc}
\hline \multirow{2}{*}{ Month } & \multicolumn{2}{c}{ PRISM weather 1984-1993 } & \multicolumn{2}{c}{ CanESM2 } \\
\cline { 2 - 5 } & $\begin{array}{c}\text { SWAT pre- } \\
\text { calibration }\end{array}$ & $\begin{array}{c}\text { SWAT post- } \\
\text { calibration }^{\mathrm{a}}\end{array}$ & $2010-2019$ & $2090-2099$ \\
\hline January & $---($ monthly sediment yield as $\%$ & of annual total)---- \\
February & 12.0 & 14.0 & 26.0 & 27.8 \\
March & 16.1 & 20.3 & 16.7 & 23.9 \\
April & 14.0 & 16.9 & 14.3 & 12.6 \\
May & 18.9 & 19.1 & 18.1 & 6.5 \\
June & 10.1 & 8.9 & 1.8 & 1.2 \\
July & 7.1 & 4.7 & 0.0 & 0.3 \\
August & 0.9 & 0.0 & 0.0 & 0.0 \\
September & 0.2 & 0.0 & 0.0 & 0.0 \\
October & 0.7 & 0.0 & 0.0 & 0.0 \\
November & 2.3 & 0.8 & 1.5 & 0.1 \\
December & 10.3 & 8.5 & 7.3 & 8.3 \\
Yearly sediment yield means and & 7.4 & 6.8 & 14.3 & 19.3 \\
standard deviations (MT.ha $\left.{ }^{-1}\right)$ & $4.35+1.75$ & $2.36+1.02$ & $3.42+1.50$ & $18.61+9.99$ \\
\hline
\end{tabular}

aAll SWAT models included full representative landuse with 3790 HRUs. Final results of 45 rounds of hydrologic calibration using real weather from 1984-1993 were applied to CanESM2.

Calibration to the Willamette River Basin increased relative sediment yield within this period to $56.3 \%$ of the annual total while reducing the absolute level of yearly sediment yield from 4.35 to $2.36 \mathrm{MT} \cdot \mathrm{ha}^{-1}$. Predictions from the CanESM2 model for 2010-2019 differed from those for the 1984-1993 calibration weather mainly in terms of greater relative sediment yield early in the winter (December and January) and decreased yield late in the spring (May and June). Conditions modeled by CanESM2 in 2090-2099 not only vastly increased the absolute quantity of soil erosion (5.44× as much as occurring 80 years earlier), but also tightened the seasonal concentration, with December through February accounting for $71 \%$ of the total annual sediment yield. In simplest terms, the unsustainable soil losses in SWAT's handling of the CanESM2 model of climate change by 2090-2099 occurred predominantly during extreme winter storms, warm enough for the heavy precipitation to fall mainly as rain rather than snow [9]. Many of the crops were modeled by SWAT as growing relatively slowly during the winter, leading to inadequate levels of ground cover to protect soils from the extreme winter storms.

\subsection{Sub-Basin Elevation and Sediment Yield}

The influence of sub-basin elevation on sediment yield was examined in detail for CanESM2, the climate model with the highest overall soil erosion, because its stronger signal facilitated our interpretation of the underlying phenomena. Plot- 
ting yearly sediment yield versus maximum elevation in each sub-basin (135 independent sub-basins with no upstream sources of water and sediment and 134 nested sub-basins with upstream sources; 105 sub-basins lying west of the Willamette River and 164 sub-basins east of it) helped subdivide the causes of erosion into separate effects of time, elevation, and landscape position (Figure 11(a) and Figure 11(b)). For the period from 2010 to 2019, most of the sub-basins experienced moderately low rates of erosion, with all but 10 of them

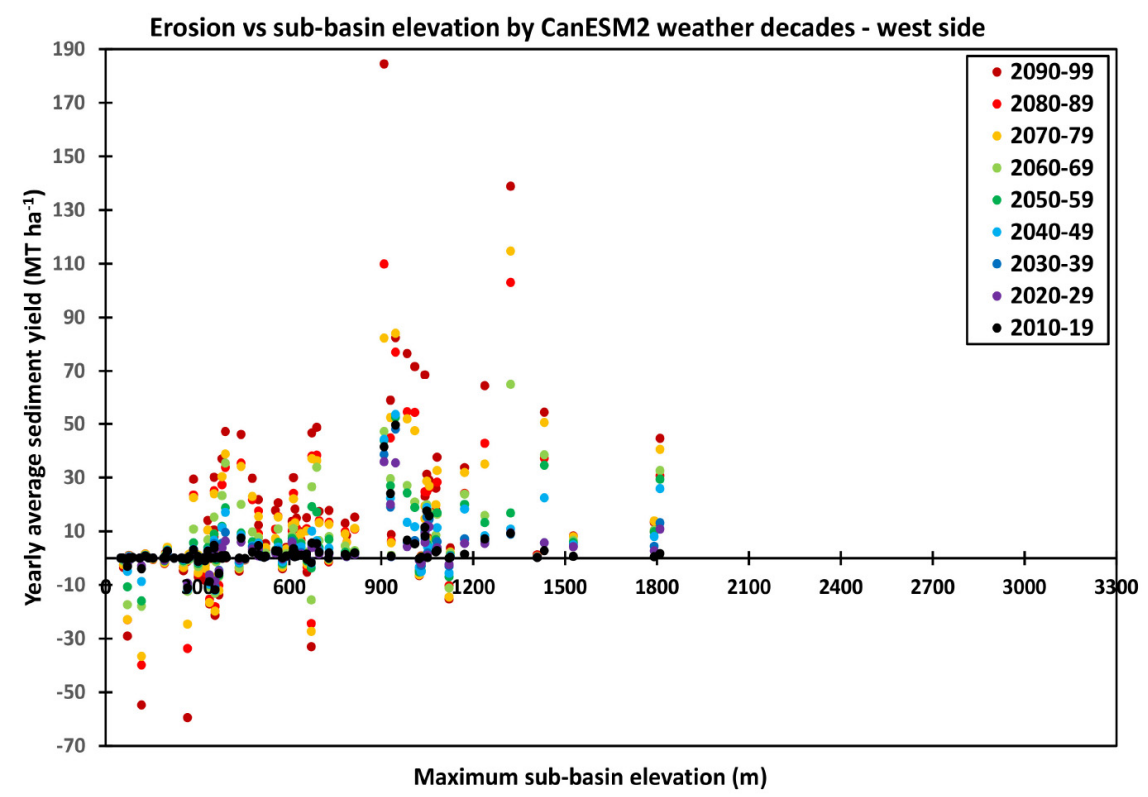

(a)

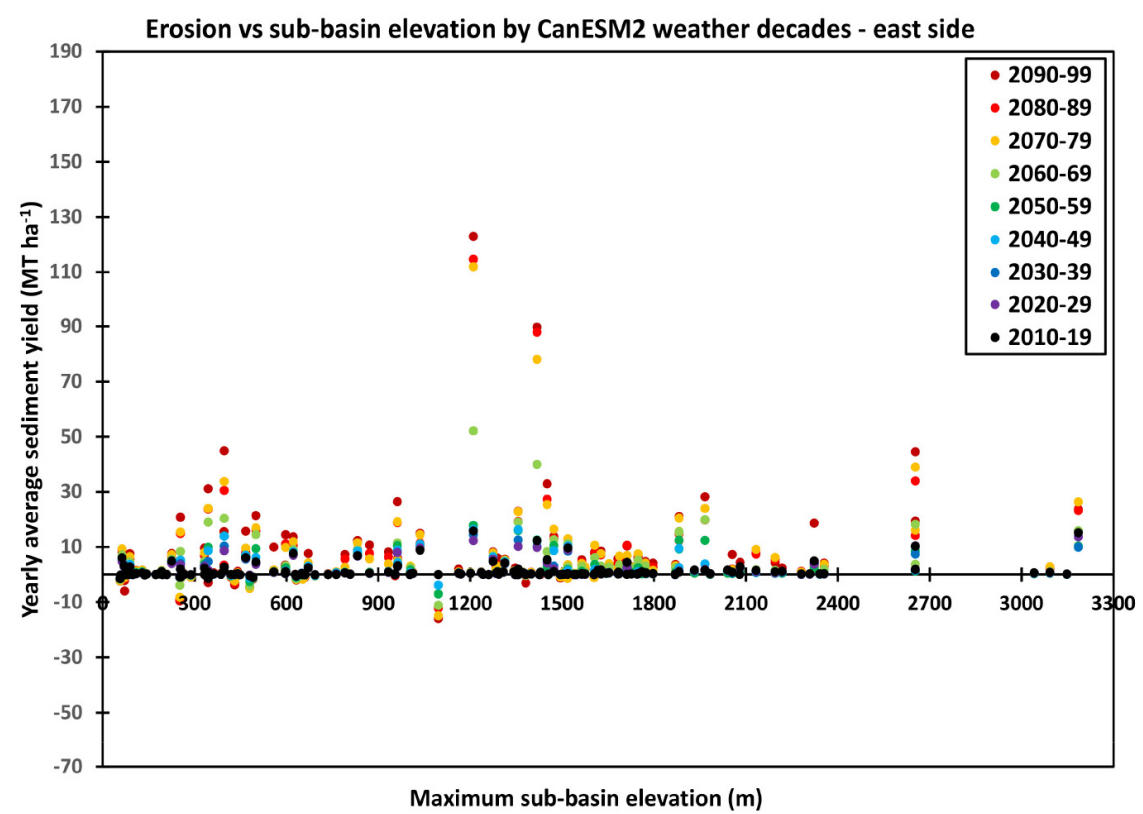

(b)

Figure 11. Yearly sediment yield as decade-long averages from the CanESM2 model versus maximum sub-basin elevation for 105 sub-basins west of Willamette River (a) and 164 sub-basins east of it (b). 
under $10 \mathrm{MT} \cdot \mathrm{ha}^{-1}$. The largest erosion in that initial decade occurred in sub-basin 79, located in the Coastal Mountain Range immediately west of Grande Ronde, OR, with a peak elevation of just over 900 masl, dominated by Honeygrove-Peavine complex soils with $3 \%$ to $30 \%$ slopes. The increase in erosion over time was dramatic for most of the sub-basins, especially so for those whose sediment yield in the first decade had already exceeded $2 \mathrm{MT} \cdot \mathrm{ha}^{-1}$. The final three decades stood out for their dramatic increases in sediment yield across most of the sub-basins whose peak elevations exceeded 250 masl. The two decades from 2050 to 2069 served as the transition period from fairly reasonable erosion rates at the start of the CanESM2 simulation to dramatic failure of landscape integrity by the end of it. Per unit area erosion was greater on the west side (Figure 11(a)) than the east side (Figure 11(b)) of the Willamette River Basin, with west- versus east-side difference in sediment yield averaging 3.1 MT.ha ${ }^{-1}$ over the entire period and climbing to $7.6 \mathrm{MT} \cdot \mathrm{ha}^{-1}$ by the final decade of the 21st century. Contributing factors included: 1 ) warmer temperatures (by an average of $0.43^{\circ} \mathrm{C}$ ) on the west side versus the east side in sub-basins at matching average altitudes, 2) higher average sub-basin altitudes on the east side versus the west side (582 versus 204 masl) retaining more of the winter precipitation as snowfall, and 3) differing soil types and topography, with younger soils and steeper topography on the west side (14.7 versus $11.4 \%$ average west-side versus east-side slopes). Precipitation, however, was an average of $158 \mathrm{~mm}$ greater in sub-basins with matching altitudes on the east side than the west side, a presumed orographic response to the prevailing direction of storm movement. Landuse differences between the west-side Coastal Mountain and the east-side Cascade Mountain Ranges likely also contributed to differences in soil erosion rates, but we have chosen not to present that full interaction level of detail.

Negative values for sediment yield versus elevation (i.e., sediment gain) illuminated the high rates of sediment deposition occurring in several of the sub-basins downstream from the sources of greatest soil loss. Highest yearly deposition rates in the final decade (nearly $60 \mathrm{MT} \cdot \mathrm{ha}^{-1}$ ) occurred in sub-basin 71 , located $12 \mathrm{~km}$ downstream from the outlet of sub-basin 79. Sediment deposition in nine other sub-basins exceeded $10 \mathrm{MT} \cdot \mathrm{ha}^{-1}$ per year for the final decade of the CanESM2 simulation. While none of these 10 sub-basins aligned precisely with locations of the 13 Willamette River Basin reservoirs, the redistribution of soil occurring in the latter decades of the 21 st century could hardly avoid having impact on operation of the reservoirs, either through deposition of sediment within the reservoirs themselves or through altered hydrologic flows in streams and rivers downstream from the reservoirs.

\subsection{Streamflow and Sediment Yield}

One commonly used method to describe overall behavior of watersheds is to express hydrologic discharge at their outlet as a percentage of total precipitation across the landscape. Several key features appeared in such summarization of the 900 model-years by their sediment yield versus streamflow/precipitation values 
(Figure 12). First, streamflow for most cases was in a range from $50 \%$ to $75 \%$ of precipitation, values common in the PNW but larger than those found for most other river basins in the US [34] [48] [49]. Second, within this range, large variability in sediment yield occurred at given levels of streamflow along with a clear trend toward higher erosion in simulation years with greater streamflow. Third, this representation of the data retained significant effects of the individual climate models (e.g., the four largest values for sediment yield all came from $\mathrm{Ca}$ nESM2 and graphed near one another). Because streamflow was strongly related to precipitation, it was logical for sediment yield to increase with streamflow. The patterns in Figure 12, however, were certainly no clearer than those for sediment yield versus precipitation in Figure 8, suggesting that temperature, snowfall, and possibly seasonal distribution patterns would all have to be included in any more elaborate analyses potentially capable of identifying additional unique roles for streamflow in determining sediment yield beyond the factors already recognized of temperature and precipitation in Figure 9 and snowfall and precipitation in Figure 10.

\subsection{Sediment Loading from Landuse Extremes}

The sensitivity of SWAT to specific details in landuse patterns was tested using several simplified 2-class cases, with numbers of HRUs correspondingly reduced from 3790 to 1160 . First, we assigned Douglas fir to the $94.5 \%$ of the landscape

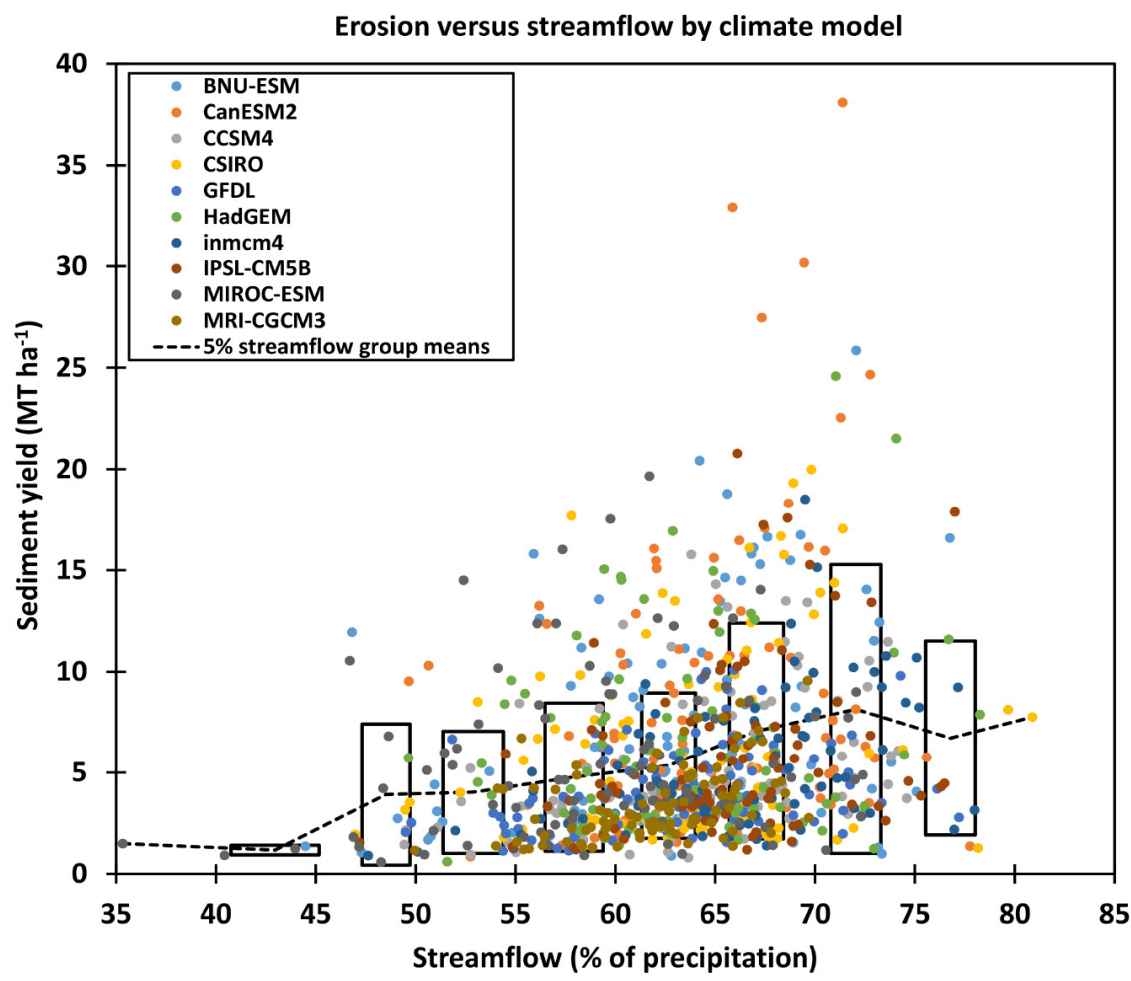

Figure 12. Sediment yield versus streamflow as percentage of annual precipitation for 10 climate models from 2010 to 2099. Dashed line connects means of data regrouped into $5 \%$ streamflow bands, with plus or minus one standard deviation boxes around the means. 
not defined as urban development and examined sediment yield for the worst case climate scenario (CanESM in the period from 2090 to 2099), using the parameter calibration values from the full 36-class landuse model. Converting all non-urban landuse into Douglas fir reduced average sediment yield for 2090-2099 to $1.47 \mathrm{MT} \cdot \mathrm{ha}^{-1}$, 92\% lower than when the currently present mixture of 36 landuses was modeled. This maximally-forested landuse model also experienced lower erosion rates in the first decade of CanESM2 simulations, dropping from 3.45 MT.ha ${ }^{-1}$ for the current mixture of 36 landuses to $0.36 \mathrm{MT} \cdot \mathrm{ha}^{-1}$ for the maximally-forested case. Next we tested how much worse things might be if the entire non-urban landscape was converted to the intermediately vulnerable case of tall fescue pasture. Converting all non-urban landuse into tall fescue pasture increased average sediment yield for 2090-2099 to 55.37 MT.ha ${ }^{-1}$, $2.97 \times$ higher than when the current mixture of 36 landuses was modeled. These differences were mainly due to two factors: 1) the change from highly erosion-resistant Douglas fir to tall fescue pasture on $64 \%$ of the landscape, and 2) changes in Dec. 31 harvest method from "harvest only at 0.8 efficiency" for many of the landuses to "harvest and kill" followed immediately by initiating regrowth for tall fescue pasture. This sensitivity existed despite use of January 1 time scheduling rather than heat unit accumulation for the start of new growth in tall fescue pasture. In the first decade of CanESM2 simulations, however, this maximally-pastured landuse model experienced slightly reduced erosion rates, dropping from 3.45 MT.ha ${ }^{-1}$ for the current mixture of 36 landuses to 1.89 MT.ha ${ }^{-1}$ for the maximally-pastured case.

\subsection{Sediment Concentrations}

In addition to the impacts of climate on rates of long-term sediment yield and redeposition across the landscape, a related concern for the hydrology of the Willamette River Basin is the predicted concentrations of suspended sediment within streams and rivers. Suspended sediments concentrations of $50 \mathrm{mg} \cdot \mathrm{L}^{-1}$, and even less in some cases, have been shown to impact behavior of salmonids and other fish, presumably through effects on vision and feeding [50]. This sediment concentration value was exceeded on a basin-outlet average in the first year of the CanESM simulation, with a 93\% increase to an average of $101 \mathrm{mg} \cdot \mathrm{L}^{-1}$ for 2090 to 2099. A full analysis of daily variation in suspended concentrations above or below this or other thresholds across the entire stream network would be a sufficiently complex undertaking to merit a separate publication. Nevertheless, given that both measured [28] and predicted concentrations of suspended sediment already often exceeded even a $50 \mathrm{mg} \cdot \mathrm{L}^{-1}$ threshold, the impact of increased sediment concentration on fish in the PNW should be considered as another negative effect of warming climate.

\subsection{Crop Growth Patterns}

Changes in crop yield or biomass production in SWAT over time and among climate models served as indicators of how well suited a given crop or landuse 
was to growing in those particular weather conditions. In addition, predictions of poor growth under changing climate may indicate additional vulnerability for soil erosion. While absolute values of crop yield or biomass production are unlikely to exactly match current conditions due to imprecise descriptions of management operations and crop growth parameters, the relative changes over time should indicate how easy or hard it may be for particular crops to grow in an altered future climate.

Crops and unmanaged vegetation types tended to fall into three distinct groups: those that are predicted to have declining productivity over time, those that have peak productivity under mid-century climate conditions (2040s-2070s), and those that have peak productivity under end-of-century climate conditions (2080s-2090s). Many individual crops followed a general pattern of maximum production in the first decade (2010-2019) followed by gradual decline over time as the climate warmed, with minimum production in 2090-2099 (Table 5). The 16 crops/landuses most clearly displaying this pattern included alfalfa, field peas, beans, mint, nursery crops, winter wheat, clover grown for seed, ryegrass grown for seed, and tall fescue grown for seed and as pasture or hay. Severity of yield loss by 2090-99 in this group exceeded $50 \%$ for winter wheat and tall fescue and ryegrass seed crops. Changes in yield over time were relatively minor for some other crops in this group, with losses of $18.0 \%$, $17.6 \%$, and $7.9 \%$ for alfalfa, clover grown for seed, and field peas, respectively. Corn and radish experienced peak production in 2020-2029 followed by relatively minor declines of $15.7 \%$ and $9.4 \%$, respectively, by $2090-2099$. Several crops, including relatively unmanaged vegetation, showed an obvious preference for some degree of warming over conditions of 2010-2019, including Douglas fir (optimum in 2070-2079), fine fescue and orchardgrass seed crops modeled as Kentucky bluegrass (optimum in 2090-2099), bentgrass grown for seed modeled as timothy (optimum in 2080-2089), and oak trees (optimum in 2090-2099) (Table 5). Factors controlling crop response to weather included water stress days, temperature stress days, nutrient stress days, and aeration stress days. Several of these stress factors include both extremes in their options (e.g., temperatures too low or too high for optimal growth even when adequate moisture was present), leading to the wide variety of responses among the crops. Consistency in response was evaluated by the number of models agreeing that a given decade was indeed the best or worst one for crop yield or biomass production. In seven cases, at most only one out of 10 climate models failed to agree as to which decade would experience maximum production. In 15 cases, at most only one out of 10 climate models failed to agree as to which decade would have minimum production. For situations in which at least seven of the 10 models agreed, there were seven crops with highly consistent identifications of both the maximum and minimum producing decades. Low temperature stress was modeled by SWAT as a factor limiting current yields of several grass crops modeled as Kentucky bluegrass or timothy, along with oak trees, Douglas fir, and varying levels of urban development (modeled as Bermuda grass). 
Table 5. Crop yield or biomass maxima and minima by decade, averaged over climate models.

\begin{tabular}{|c|c|c|c|c|c|c|c|}
\hline \multirow{2}{*}{$\begin{array}{l}\text { Crop or landuse } \\
\text { (Y for crop yield, } \\
\text { B for biomass) }\end{array}$} & \multicolumn{3}{|c|}{ Maximum production } & \multicolumn{3}{|c|}{ Minimum production } & \multirow[b]{2}{*}{ Min: Max } \\
\hline & $\begin{array}{l}\text { Crop yield } \\
\text { or biomass }\end{array}$ & Decade & $\begin{array}{c}\text { Models } \\
\text { agree }^{\mathrm{a}}\end{array}$ & $\begin{array}{l}\text { Crop yield or } \\
\text { biomass }\end{array}$ & Decade & $\begin{array}{c}\text { Models } \\
\text { agree }^{\mathrm{a}}\end{array}$ & \\
\hline & $\mathrm{kg} \cdot \mathrm{ha}^{-1}$ & years & count & $\mathrm{kg} \cdot \mathrm{ha}^{-1}$ & years & count & ratio \\
\hline (Y) Alfalfa & 3631 & 2010-19 & 9 & 2977 & $2090-99$ & 8 & 0.820 \\
\hline (Y) Filberts (modeled as cashew) & 3289 & 2010-19 & 6 & 2705 & $2090-99$ & 4 & 0.823 \\
\hline (Y) Clover for seed & 9718 & 2010-19 & 3 & 8003 & $2090-99$ & 8 & 0.824 \\
\hline (Y) Tall fescue for seed & 8960 & 2010-19 & 5 & 912 & $2090-99$ & 10 & 0.102 \\
\hline (Y) Fall plant clover & 10497 & $2010-19$ & 5 & 8527 & $2090-99$ & 7 & 0.812 \\
\hline (Y) Field peas & 3322 & 2010-19 & 3 & 3059 & $2090-99$ & 4 & 0.921 \\
\hline (Y) Green beans & 679 & 2010-19 & 4 & 437 & $2090-99$ & 9 & 0.644 \\
\hline (Y) Annual/perennial ryegrass for seed & 10924 & 2010-19 & 9 & 4832 & $2090-99$ & 9 & 0.442 \\
\hline (Y) Mint & 1182 & 2010-19 & 9 & 950 & $2090-99$ & 4 & 0.804 \\
\hline (Y) Nursery crops & 7066 & 2010-19 & 5 & 6110 & $2090-99$ & 7 & 0.865 \\
\hline (B) wildlife refuge/shrub (RNGE) & 3335 & 2010-19 & 5 & 2282 & $2090-99$ & 10 & 0.684 \\
\hline (Y) Spring plant grass seed & 5573 & 2010-19 & 6 & 3340 & $2090-99$ & 9 & 0.599 \\
\hline (Y) Tall fescue haycrop & 1967 & 2010-19 & 8 & 1332 & $2090-99$ & 7 & 0.677 \\
\hline (Y) Tall fescue pasture & 2005 & 2010-19 & 8 & 1330 & $2090-99$ & 10 & 0.663 \\
\hline (B) Wetland, forested & 5858 & 2010-19 & 9 & 5125 & $2090-99$ & 8 & 0.875 \\
\hline (Y) Winter wheat & 2033 & 2010-19 & 9 & 788 & $2090-99$ & 7 & 0.388 \\
\hline (Y) Corn & 8009 & $2020-29$ & 3 & 6750 & $2090-99$ & 9 & 0.843 \\
\hline (Y) Radish & 5604 & $2020-29$ & 5 & 5080 & $2090-99$ & 6 & 0.906 \\
\hline (B) Open water & 171 & $2020-29$ & 4 & 164 & $2090-99$ & 1 & 0.962 \\
\hline (Y) Hops (modeled as coffee) & 1491 & 2010-19 & 6 & 1048 & $2080-89$ & 3 & 0.703 \\
\hline (Y) Orchards (modeled as apple) & 1869 & 2010-19 & 7 & 1406 & $2050-59$ & 2 & 0.752 \\
\hline (Y) Vineyards & 2241 & 2010-19 & 10 & 966 & $2050-59$ & 5 & 0.431 \\
\hline (B) Forest mixed & 3095 & $2040-49$ & 2 & 2939 & 2010-19 & 7 & 0.950 \\
\hline (B) Wetland, non-forested & 1535 & $2040-49$ & 5 & 1358 & 2010-19 & 4 & 0.884 \\
\hline (B) Forest deciduous & 3503 & $2060-69$ & 4 & 3266 & 2010-19 & 9 & 0.932 \\
\hline (B) Douglas fir & 5633 & $2070-79$ & 4 & 4551 & 2010-19 & 10 & 0.808 \\
\hline (B) Barren & 528 & $2080-89$ & 4 & 324 & 2010-19 & 10 & 0.615 \\
\hline (B) Urban development (modeled as Bermuda grass) & 23685 & $2080-89$ & 2 & 15287 & $2010-19$ & 10 & 0.645 \\
\hline (B) Fallow (modeled as eggplant) & 53 & $2080-89$ & 5 & 39 & 2010-19 & 6 & 0.735 \\
\hline (B) scrub/shrub (NLCD 53, RNGB) & 1828 & $2080-89$ & 1 & 1273 & 2010-19 & 10 & 0.696 \\
\hline (Y) Bentgrass for seed (modeled as timothy) & 12869 & $2080-89$ & 3 & 178 & 2010-19 & 4 & 0.014 \\
\hline (B) Fine fescue for seed (modeled as Kentucky bluegrass) & 16614 & 2090-99 & 8 & 6909 & 2010-19 & 10 & 0.416 \\
\hline (B) Orchardgrass for seed (modeled as Kentucky bluegrass) & 13686 & 2090-99 & 10 & 1578 & 2010-19 & 10 & 0.115 \\
\hline (B) Oak trees & 7237 & $2090-99$ & 6 & 5167 & $2010-19$ & 10 & 0.714 \\
\hline
\end{tabular}

${ }^{a}$ Count is number out of 10 climate models agreeing as to which specific decade had highest or lowest harvestable crop yield or total above-ground biomass production. 
Recent publications of the impact of climate change on non-irrigated wheat in the inland PNW found the potential for $29 \%$ to $64 \%$ higher grain yield by 2070 , assuming adaptations such as use of earlier planting dates for spring wheat, earlier maturing cultivars in both winter and spring wheat, and spatially-varying transitions between annual cropping and alternating wheat/fallow rotation [51]. A meta-analysis of multiple wheat production studies worldwide under changing climate found reduced yields in a majority of cases when temperature increases exceeded $2.3^{\circ} \mathrm{C}$ above recent norms [52]. A comparison of 30 different agricultural models for wheat found that even the current extent of warming has slowed gains in yield that should have been seen from use of modern germplasm, fertilization, and pest control practices, with future global production anticipated to increase in variability while it falls by an average of $6 \%$ for each $1.0^{\circ} \mathrm{C}$ of further warming [53]. Approaches that may be used as inland PNW agriculture adapts to changing climate include substitution of winter for spring crops and both diversification and intensification of cropping systems to take advantage of those portions of the growing season that are becoming more favorable while avoiding the increased heat of the summer.

\subsection{How Reasonably Do RCP8.5 and SWAT Combine?}

SWAT is designed as an interlinked series of continuous, primarily linear, functions operating on a daily time step basis to model real-world behavior of plant growth and development, crop harvest, leaf litter accumulation, soil erosion, nutrient cycling, and both surface and below-ground water flow and storage. Given this design, the appearance of chaotic behavior in sediment yield is a warning that the CIMP5 RCP8.5 weather data in the latter half of the $21^{\text {st }}$ century is "out of sync" with some of the underlying assumptions used by SWAT to model crop growth and development, route water, and predict transport of sediment and nutrients. The simplest expression of SWAT's required assumptions is that the future being modeled must be very much like the recent past used to define values for parameters describing plant growth, crop management, and landscape hydrology.

As one alternative to simply accepting the validity of RCP8.5 weather data (or arguing over it), we created our own "synthetic weather" by realigning short periods $(4,7$, or 14-day lengths) of real data from 66 years of observations on the basis of their ranking by temperature on a given set of calendar days over artificial years adjusted at the end of December to yield exactly 91, 52, or 26 such periods per year. These synthetic weather records covered a range in warming relative to historical means similar to that of the RCP8.5 data, as well as a cooling phase not present there. Sediment yield was essentially unchanged during synthetic cooling below historical averages, while exponentially increasing during synthetic warming above them. As precipitation also increased during synthetic warming, the catastrophic levels of sediment yield in the most extreme cases were the combined result of higher rain-snow transition zones, greater winter precipitation, and altered patterns of plant growth. Common features of the 
nonlinear tipping points found by SWAT in both CIMP5 RCP8.5 and our synthetic weather were the wet, warm winter storms lacking adequate snow to protect soil from severe erosion. Such events have happened throughout modern history, but only for relatively small numbers of days at a time while sandwiched in between longer periods of other (more normal) weather conditions, typically drier, cooler, or both.

Alternate approaches for studying extreme precipitation events in the western U.S. have shown compatibility between CIMP5 RCP8.5 modeling data, historical weather records, particularly the "atmospheric river of moisture" phenomenon, and the underlying physical processes [54] [55] [56]. The most worrisome finding in these studies was that the most extreme rainfall events were likely to increase in both frequency and intensity as the climate warms further. Warming in a range of 2.5 through $3.5^{\circ} \mathrm{C}$ above historic norms was enough to cause SWAT to transition into chaotic behavior in terms of sediment yield. Warming beyond $5^{\circ} \mathrm{C}$ above historic norms would transition the PNW into an environment where no subsets of historic weather could serve as useful proxies, and even revised SWAT models fully calibrated for the current extremes in hydrology and sediment yield would be extrapolations into the unknown.

\section{Conclusions}

- CMIP5 climate models simulating the RCP8.5 emissions scenario forecast $2.6^{\circ} \mathrm{C}-5.7^{\circ} \mathrm{C}$ warming in western Oregon by $2090-2099$ relative to conditions in 2010-2019, along with changes in annual precipitation ranging from -78 to $+219 \mathrm{~mm}$.

- SWAT simulations suggest that single-year departures above historical norms of 2 to $7 \mathrm{MT} \cdot \mathrm{ha}^{-1}$ for soil erosion may begin to occur within the next 30 years in some climate models and become common by 50 years in the future for most climate models, in reference to the timing of RCP8.5 scenarios.

- Annual rates of sediment yield were highly sensitive to precipitation, while trends in decadal average sediment yield showed stronger relationships with warming temperatures than with changing precipitation, the extent of which varied among models. Loss of snow associated with warmer winters was the common factor in all these trends.

- Soil erosion rates in the worst case scenarios have the potential to strip topsoil from vulnerable landuses (those possessing little to no ground cover during the winter) in a century or two. Because values for sediment loss in SWAT are highly sensitive to details provided in descriptions of crops and their associated management practices, the strongest statement we can make is that conditions in the warmer, later years of the RCP8.5 data lie outside of those reliably handled by a SWAT model calibrated in the cooler (i.e., "more normal") conditions of the 1980s.

- Many currently grown crops (such as cool season grasses grown for seed) are projected to face yield losses as temperatures increase. Results from SWAT are too sensitive to choices for values of its internal parameters to reliably 
predict which specific crops farmers may be forced to replace with alternatives better adapted to warmer environments at which particular points in time.

- Specific rates of soil erosion calculated by SWAT depend on choices for management operations and plant growth parameters, which interact with temperature and precipitation to produce daily estimates of crop growth, accumulated biomass/ground cover, and susceptibility of soil to erosion by water. The actual consequences to the environment in western Oregon will likely deviate from the results of these 10 climate models and our version of landuse/plant growth in SWAT. Possible causes for the real world presence of bare ground in the landscape (that may or may not have been modeled by SWAT) include: 1) poor adaptation of some current species to higher temperatures and more extreme moisture stress in future summers, 2) sudden large-scale defoliation from wildfires or epidemics of foliar diseases or damaging insects, and 3) deliberate agricultural and forestry management decisions to remove existing vegetation through harvest, tillage, or herbicide treatment in the process of planting new crops. An example of one possible non-linear "tipping-point" transition would be catastrophic erosion in winters immediately following loss of forest integrity from wildfires on the scale of the 1933 Tillamook Burn in their preceding summers.

- Our inability to include sediment yield while calibrating SWAT to the hydrology of western Oregon leaves undesirable uncertainty in the exact magnitude of increased erosion as climate warms, in addition to questions regarding the proportion of upland erosion versus streambank failure as sources of the sediment. The predictions from SWAT underscore the importance of obtaining additional, unbiased data on the levels and sources of suspended sediment present in the Willamette River and its tributaries during the warmest, wettest storms currently occurring in winter-time.

\section{Acknowledgements}

This research did not receive any specific grant from funding agencies in the public, commercial, or not-for-profit sectors. This work is a contribution of the United State Department of Agriculture, Agricultural Research Service. The use of trade, firm, or corporation names in this publication is for the information and convenience of the reader. Such use does not constitute an official endorsement or approval by the United States Department of Agriculture or the Agricultural Research Service of any product or service to the exclusion of others that may be suitable.

\section{Conflicts of Interest}

The authors declare no conflicts of interest regarding the publication of this paper. 


\section{References}

[1] Dalton, M.M., Dello, K.D., Hawkins, L., Mote, P.W. and Rupp, D.E. (2017) The Third Oregon Climate Assessment Report. Oregon Climate Change Research Institute, College of Earth, Ocean and Atmospheric Sciences, Oregon State University, Corvallis. http://www.occri.net/media/1042/ocar3_final_125_web.pdf

[2] Chang, H., Jones, J., Gannett, M., Tullos, D., Moradkhani, H., Vache, K., Parandvash, H., Shandas, V., Nolin, A., Fountain, A., Johnson, S., Jung, I.-W., House-Peters, L., Steele, M. and Copeland, B. (2010) Climate Change and Freshwater Resources in Oregon. In: Dello, K.D. and Mote, P.W., Eds., First Oregon Climate Assessment Report, Oregon Climate Change Research Institute, College of Oceanic and Atmospheric Sciences, Oregon State University, Corvallis, 71-151. https://core.ac.uk/download/pdf/37776398.pdf

[3] Chang, H. and Jung, I.-W. (2010) Spatial and Temporal Changes in Runoff Caused by Climate Change in a Complex Large River Basin in Oregon. Journal of Hydrology, 388, 186-207. https://doi.org/10.1016/j.jhydrol.2010.04.040

[4] Raymondi, R.R., Cuhaciyan, J.E., Glick, P., Capalbo, S.M., Houston, L.L., Shafer, S.L. and Grah, O. (2013) Water Resources: Implications of Changes in Temperature and Precipitation: Chapter 3. In: Dalton, M.M., Mote, P.W. and Snover, A.K., Eds., Climate Change in the Northwest. Implications for Our Landscapes, Waters, and Communities, Island Press, Washington DC, 41-66.

https://doi.org/10.5822/978-1-61091-512-0_3

[5] Tohver, I.M., Hamlet, A.F. and Lee, S.-Y. (2014) Impacts of 21st-Century Climate Change on Hydrologic Extremes in the Pacific Northwest Region of North America. JAWRA Journal of the American Water Resources Association, 50, 1461-1476. https://doi.org/10.1111/jawr.12199

[6] Vano, J.A., Nijssen, B. and Lettenmaier, D.P. (2015) Seasonal Hydrologic Responses to Climate Change in the Pacific Northwest. Water Resources Research, 51, 1959-1976. https://doi.org/10.1002/2014WR015909

[7] Rupp, D.E., Abatzoglou, J.T. and Mote, P.W. (2016) Projections of 21st Century Climate of the Columbia River Basin. Climate Dynamics, 49, 1-17.

https://doi.org/10.1007/s00382-016-3418-7

[8] Warner, M.D., Mass, C.F. and Salathé, E.P. (2015) Changes in Winter Atmospheric Rivers along the North American West Coast in CMIP5 Climate Models. Journal of Hydrometeorology, 16, 118-128. https://doi.org/10.1175/JHM-D-14-0080.1

[9] Klos, P.Z., Link, T.E. and Abatzoglou, J.T. (2014) Extent of the Rain-Snow Transition Zone in the Western U.S. under Historic and Projected Climate: Climatic Rain-Snow Transition Zone. Geophysical Research Letters, 41, 4560-4568. https://doi.org/10.1002/2014GL060500

[10] Abbaspour, K.C., Rouholahnejad, E., Vaghefi, S., Srinivasan, R., Yang, H. and Klove, B. (2015) A Continental-Scale Hydrology and Water Quality Model for Europe: Calibration and Uncertainty of a High-Resolution Large-Scale SWAT Model. Journal of Hydrology, 524, 733-752. https://doi.org/10.1016/j.jhydrol.2015.03.027

[11] Douglas-Mankin, K.R., Srinivasan, R. and Arnold, J.G. (2010) Soil and Water Assessment Tool (SWAT) Model: Current Developments and Applications. Transactions of the ASABE, 53, 1423-1431. https://doi.org/10.13031/2013.34915

[12] Panagopoulos, Y., Gassman, P.W., Jha, M.K., Kling, C.L., Campbell, T., Srinivasan, R., White, M. and Arnold, J.G. (2015) A Refined Regional Modeling Approach for the Corn Belt-Experiences and Recommendations for Large-Scale Integrated Modeling. Journal of Hydrology, 524, 348-366. 
https://doi.org/10.1016/j.jhydrol.2015.02.039

[13] Mote, P.W., Rupp, D.E., Li, S., Sharp, D.J., Otto, F., Uhe, P.F., Xiao, M., Lettenmaier, D.P., Cullen, H. and Allen, M.R. (2016) Perspectives on the Causes of Exceptionally Low 2015 Snowpack in the Western United States. Geophysical Research Letters, 43, 10,980-10,988. https://doi.org/10.1002/2016GL069965

[14] McClain, K. and Castro, H. (2017) 2015 Drought and Agriculture (No. AGR PUB 104-495 (N/2/17)). Washington State Department of Agriculture, Olympia. https://agr.wa.gov/FP/Pubs/docs/495-2015DroughtReport.pdf

[15] Praskievicz, S. and Chang, H. (2011) Impacts of Climate Change and Urban Development on Water Resources in the Tualatin River Basin, Oregon. Annals of the American Association of Geographers, 101, 249-271. https://doi.org/10.1080/00045608.2010.544934

[16] Marshall, E. and Randhir, T. (2008) Effect of Climate Change on Watershed System: A Regional Analysis. Climatic Change, 89, 263-280. https://doi.org/10.1007/s10584-007-9389-2

[17] Ficklin, D.L., Stewart, I.T. and Maurer, E.P. (2013) Effects of Climate Change on Stream Temperature, Dissolved Oxygen, and Sediment Concentration in the Sierra Nevada in California: Sierra Nevada Water Quality under Climate Change. Water Resources Research, 49, 2765-2782. https://doi.org/10.1002/wrcr.20248

[18] Xu, H. and Peng, S. (2013) Distinct Effects of Temperature Change on Discharge and Non-Point Pollution in Subtropical Southern China by SWAT Simulation. $\mathrm{Hy}^{-}$ drological Sciences Journal, 58, 1032-1046. https://doi.org/10.1080/02626667.2013.797579

[19] Li, Y., Chen, B.-M., Wang, Z.-G. and Peng, S.-L. (2011) Effects of Temperature Change on Water Discharge, and Sediment and Nutrient Loading in the Lower Pearl River Basin Based on SWAT Modelling. Hydrological Sciences Journal, 56, 68-83. https://doi.org/10.1080/02626667.2010.538396

[20] Ficklin, D.L., Luo, Y., Luedeling, E., Gatzke, S.E. and Zhang, M. (2010) Sensitivity of Agricultural Runoff Loads to Rising Levels of $\mathrm{CO}_{2}$ and Climate Change in the San Joaquin Valley Watershed of California. Environmental Pollution, 158, 223-234. https://doi.org/10.1016/j.envpol.2009.07.016

[21] ArcSWAT 2012.10.19 (2017) Version 2012.10_4.19 Updated Jan. 23, 2017. http://swat.tamu.edu/software/arcswat

[22] Neitsch, S.L., Arnold, J.G., Kiniry, J.R. and Williams, J.R. (2011) SWAT: Soil and Water Assessment Tool Theoretical Documentation Version 2009. USDA, ARS, Temple. https://swat.tamu.edu/media/99192/swat2009-theory.pdf

[23] Neitsch, S.L., Arnold, J.G., Kiniry, J.R. and Williams, J.R. (2001) SWAT: Soil and Water Assessment Tool User's Manual. USDA, ARS, Temple. https://swat.tamu.edu/media/1294/swatuserman.pdf

[24] Chien, H., Yeh, P.J.-F. and Knouft, J.H. (2013) Modeling the Potential Impacts of Climate Change on Streamflow in Agricultural Watersheds of the Midwestern United States. Journal of Hydrology, 491, 73-88. https://doi.org/10.1016/j.jhydrol.2013.03.026

[25] Koirala, S.R. and Gentry, R.W. (2012) SWAT and Wavelet Analysis for Understanding the Climate Change Impact on Hydrologic Response. Open Journal of Modern Hydrology, 2, 41-48. https://doi.org/10.4236/ojmh.2012.22006

[26] Santhi, C., Arnold, J.G., Williams, J.R., Dugas, W.A., Srinivasan, R. and Hauck, L.M. (2001) Validation of the SWAT Model on a Large River Basin with Point and Non- 
point Sources. JAWRA Journal of the American Water Resources Association, 37, 1169-1188. https://doi.org/10.1111/j.1752-1688.2001.tb03630.x

[27] Mueller-Warrant, G.W., Whittaker, G.W., Griffith, S.M., Banowetz, G.M., Dugger, B.D., Garcia, T.S., Giannico, G., Boyer, K.L. and McComb, B.C. (2011) Remote Sensing Classification of Grass Seed Cropping Practices in Western Oregon. International Journal of Remote Sensing, 32, 2451-2480.

https://doi.org/10.1080/01431161003698351

[28] Mueller-Warrant, G.W., Griffith, S.M., Whittaker, G.W., Banowetz, G.M., Pfender, W.F., Garcia, T.S. and Giannico, G. (2012) Impact of Landuse Patterns and Agricultural Practices on Water Quality in the Calapooia River Basin of Western Oregon. Journal of Soil and Water Conservation, 67, 183-201. https://doi.org/10.2489/jswc.67.3.183

[29] Mueller-Warrant, G.W., Griffith, S.M., Banowetz, G.M., Whittaker, G.W. and Trippe, K.M. (2014) Inferring Crop Stand Age and Landuse Duration in the Willamette Valley from Remotely Sensed Data. In: Hulting, A.G., Ed., Seed Production Research, Oregon State University Extension and USDA-ARS, Corvallis, 49-53. https://cropandsoil.oregonstate.edu/sites/agscid7/files/crop-soil/mueller_stand_age. pdf

[30] Mueller-Warrant, G.W., Whittaker, G.W., Banowetz, G.M., Griffith, S.M. and Barnhart, B.L. (2015) Methods for Improving Accuracy and Extending Results beyond Periods Covered by Traditional Ground-Truth in Remote Sensing Classification of a Complex Landscape. International Journal of Applied Earth Observation and Geoinformation, 38, 115-128. https://doi.org/10.1016/j.jag.2015.01.001

[31] Mueller-Warrant, G.W., Sullivan, C., Anderson, N. and Whittaker, G.W. (2016) Detecting and Correcting Logically Inconsistent Crop Rotations and Other Land-Use Sequences. International Journal of Remote Sensing, 37, 29-59. https://doi.org/10.1080/01431161.2016.1184354

[32] Abatzoglou, J.T. (2013) Development of Gridded Surface Meteorological Data for Ecological Applications and Modelling. International Journal of Climatology, 33, 121-131. https://doi.org/10.1002/joc.3413

[33] Abatzoglou, J.T. and Brown, T.J. (2012) A Comparison of Statistical Downscaling Methods Suited for Wildfire Applications. International Journal of Climatology, 32, 772-780. https://doi.org/10.1002/joc.2312

[34] Eisner, S., Florke, M., Chamorro, A., Daggupati, P., Donnelly, C., Huang, J., Hundecha, Y., Koch, H., Kalugin, A., Krylenko, I., Mishra, V., Piniewski, M., Samaniego, L., Seidou, O., Wallner, M. and Krysanova, V. (2017) An Ensemble Analysis of Climate Change Impacts on Streamflow Seasonality across 11 Large River Basins. Climate Change, 141, 401-417. https://doi.org/10.1007/s10584-016-1844-5

[35] Livneh, B., Rosenberg, E.A., Lin, C., Mishra, V., Andreadis, K., Maurer, E.P. and Lettenmaier, D.P. (2013) A Long-Term Hydrologically Based Dataset of Land Surface Fluxes and States for the Conterminous United States: Update and Extensions. Journal of Climate, 26, 9384-9392. https://doi.org/10.1175/JCLI-D-12-00508.1

[36] Taylor, K.E., Stouffer, R.J. and Meehl, G.A. (2012) An Overview of CMIP5 and the Experiment Design. Bulletin of the American Meteorological Society, 93, 485-498. https://doi.org/10.1175/BAMS-D-11-00094.1

[37] Jha, M., Gassman, P.W., Secchi, S., Gu, R. and Arnold, J. (2004) Effects of Watershed Subdivision on SWAT Flow, Sediment and Nutrient Predictions. JAWRA Journal of the American Water Resources Association, 40, 811-825. https://doi.org/10.1111/j.1752-1688.2004.tb04460.x 
[38] PRISM Climate Group (2004) Oregon State University, Created 4 Feb. 2004. http://prism.oregonstate.edu

[39] Moriasi, D.N., Arnold, J.G., Van Liew, M.W., Bingner, R.L., Harmel, R.D. and Veith, T.L. (2007) Model Evaluation Guidelines for Systematic Quantification of Accuracy in Watershed Simulations. Transactions of the ASABE, 50, 885-900. https://doi.org/10.13031/2013.23153

[40] Nash, J.E. and Sutcliffe, J.V. (1970) River Flow Forecasting through Conceptual Models Part I-A Discussion of Principles. Journal of Hydrology, 10, 282-290. https://doi.org/10.1016/0022-1694(70)90255-6

[41] Kline, T. and Bahus, K. (1999) Willamette Basin Reservoirs. The Willamette Basin Reservoir Study, 8 p.

https://www.oregon.gov/OWRD/wrdpublications1/1998_04_Willamette_Brochure. pdf

[42] Harward, M.E., Kling, G.F. and Istok, J.D. (1980) Erosion, Sediment, and Water Quality in the High Winter Rainfall Zone of the Northwestern United States. Special Report 602, Agricultural Experiment Station, Corvallis, 220 p.

[43] Natural Resources Conservation Service, United States Dept. of Agriculture (2017) Soil Survey of Benton County, Oregon.

https://www.nrcs.usda.gov/wps/portal/nrcs/soilsurvey/soils/survey/state

[44] Wise, D.R. and O’Connor, J.E. (2016) A Spatially Explicit Suspended-Sediment Load Model for Western Oregon. U.S. Geological Survey Scientific Investigations Report 2016-5079, 25 p. https://doi.org/10.3133/sir20165079

[45] Sobieszczyk, S., Bragg, H.M. and Uhrich, M.A. (2015) Water-Quality Conditions and Suspended-Sediment Transportin the Wilson and Trask Rivers, Northwestern Oregon, Water Years 2012-14. U.S. Geological Survey Scientific Investigations Report 2015-5109, 32 p. https://doi.org/10.3133/sir20155109

[46] Abatzoglou, J.T., Rupp, D.E. and Mote, P.W. (2014) Seasonal Climate Variability and Change in the Pacific Northwest of the United States. Journal of Climate, 27, 2125-2142. https://doi.org/10.1175/JCLI-D-13-00218.1

[47] Mote, P.W. (2003) Trends in Temperature and Precipitation in the Pacific Northwest. Northwest Science, 77, 271-282.

[48] Istok, J.D., Boersma, L., Hickman, J.S., Harward, M.E., Kling, G.F. and Vomocil, J.A. (1985) Statistical Analysis of Hydrological Data from Five Small Watersheds in Western Oregon Volume I: Analysis. Special Report 740, Agricultural Experiment Station, Corvallis, 47 p. https://ir.library.oregonstate.edu/downloads/nz806075h

[49] Istok, J.D., Boersma, L., Hickman, J.S., Harward, M.E., Kling, G.F. and Vomocil, J.A. (1985) Statistical Analysis of Hydrological Data from Five Small Watersheds in Western Oregon Volume II: Data. Special Report 741, Agricultural Experiment Station, Corvallis, 178 p. https://ir.library.oregonstate.edu/downloads/05741s66n

[50] Newcombe, C.P. and McDonald, D.D. (1991) Effects of Suspended Sediments on Aquatic Ecosystems. North American Journal of Fisheries Management, 11, 72-82. https://doi.org/10.1577/1548-8675(1991)011<0072:EOSSOA>2.3.CO;2

[51] Karimi, T., Stöckle, C.O., Higgins, S. and Nelson, R. (2018) Climate Change and Dryland Wheat Systems in the US Pacific Northwest. Agricultural Systems, 159, 144-156. https://doi.org/10.1016/j.agsy.2017.03.014

[52] Wilcox, J. and Makowski, D. (2014) A Meta-Analysis of the Predicted Effects of Climate Change on Wheat Yields Using Simulation Studies. Field Crops Research, 156, 180-190. https://doi.org/10.1016/j.fcr.2013.11.008 
[53] Asseng, S., Ewert, F., Martre, P., et al. (2014) Rising Temperatures Reduce Global Wheat Production. Nature Climate Change, 5, 143-147.

http://www.nature.com/doifinder/10.1038/nclimate2470 https://doi.org/10.1038/nclimate2470

[54] Dettinger, M., Ralph, F.M. and Rutz, J.J. (2018) Empirical Return Periods of the Most Intense Vapor Transports during Historical Atmospheric River Landfalls on the U.S. West Coast. Journal of Hydrometeorology, 19, 1363-1377.

https://doi.org/10.1175/JHM-D-17-0247.1

[55] Gershunov, A., Shulgina, T., Ralph, F.M., Lavers, D.A. and Rutz, J.J. (2017) Assessing the Climate-Scale Variability of Atmospheric Rivers Affecting Western North America. Geophysical Research Letters, 44, 7900-7908. https://doi.org/10.1002/2017GL074175

[56] Chen, X., Hossain, F. and Leung, L.R. (2017) Probable Maximum Precipitation in the U.S. Pacific Northwest in a Changing Climate. Water Resources Research, 53, 9600-9622. https://doi.org/10.1002/2017WR021094 